\title{
Interactive effects of anthropogenic nitrogen enrichment and climate change on terrestrial and aquatic biodiversity
}

\author{
Ellen M. Porter • William D. Bowman • \\ Christopher M. Clark • Jana E. Compton • \\ Linda H. Pardo $\cdot$ Jenny L. Soong
}

Received: 11 June 2012/Accepted: 1 October 2012/Published online: 20 October 2012

(C) The Author(s) 2012. This article is published with open access at Springerlink.com

\begin{abstract}
Biodiversity has been described as the diversity of life on earth within species, among species, and among ecosystems. The rate of biodiversity loss due to human activity in the last 50 years has been more rapid than at any other time in human history, and many of the drivers of biodiversity loss are increasing, including habitat loss, overexploitation, invasive species, climate change, and pollution, including pollution from reactive nitrogen $(\mathrm{Nr})$. Of these stressors, climate change and $\mathrm{Nr}$
\end{abstract}

Electronic supplementary material The online version of this article (doi:10.1007/s10533-012-9803-3) contains supplementary material, which is available to authorized users.

E. M. Porter ( $\square)$

Air Resources Division, National Park Service,

Denver, CO, USA

e-mail: ellen_porter@nps.gov

W. D. Bowman

University of Colorado, Boulder, CO, USA

C. M. Clark

US Environmental Protection Agency, Washington, DC, USA

J. E. Compton

US Environmental Protection Agency, Corvallis, OR, USA

L. H. Pardo

USDA Forest Service, Burlington, VT, USA

J. L. Soong

Colorado State University, Fort Collins, CO, USA from anthropogenic activities are causing some of the most rapid changes. Climate change is causing warming trends that result in poleward and elevational range shifts of flora and fauna, and changes in phenology, particularly the earlier onset of spring events and migration, and lengthening of the growing season. Nitrogen $(\mathrm{N})$ enrichment can enhance plant growth, but has been shown to favor, fast-growing, sometimes invasive, species over native species adapted to low $\mathrm{N}$ conditions. Although there have been only a few controlled studies on climate change and $\mathrm{N}$ interactions, inferences can be drawn from various field observations. For example, in arid ecosystems of southern California, elevated $\mathrm{N}$ deposition and changing precipitation patterns have promoted the conversion of native shrub communities to communities dominated by annual non-native grasses. Both empirical studies and modeling indicate that $\mathrm{N}$ and climate change can interact to drive losses in biodiversity greater than those caused by either stressor alone. Reducing inputs of anthropogenic $\mathrm{Nr}$ may be an effective mitigation strategy for protecting biodiversity in the face of climate change.

Keywords Climate change $\cdot$ Reactive nitrogen · Biodiversity

\section{Introduction}

Biodiversity is the foundation of the integrity, resilience and beauty of nature. Simply defined, biodiversity is the variety of life on earth, including all species, 
the diversity of genes in these species, and the communities and ecosystems they inhabit. A more complete definition from the Convention on Biological Diversity states:

Biological diversity means the variability among living organisms from all sources including, inter alia, terrestrial, marine and other aquatic ecosystems and the ecological complexes of which they are part; this includes diversity within species, between species and of ecosystems" (CBD 1992).

Biodiversity influences-either directly or indirectly-nearly every ecological process. Changes in biodiversity alter the structure and function of ecosystems which can, in turn, affect the production of ecosystem services and human well-being in a variety of ways (Chapin et al. 2000; Millennium Ecosystems Assessment (MEA) 2005; Secretariat of the Convention on Biological Diversity 2010). Biodiversity is positively associated with a number of key ecosystem processes, in particular primary and secondary productivity, resistance to invasion and consumption, erosion control, and nutrient cycling (Balvanera et al. 2006). The benefits of biodiversity become more apparent when multiple ecosystem functions are considered because different species often perform different functions in ecosystems, or at different times (Hector and Bagchi 2007; Scherber et al. 2010; Zavaleta et al. 2010). More biodiverse systems tend to be more stable when processes are measured either through time (Hector et al. 2010; Yachi and Loreau 1999; Tilman et al. 1998) or over larger spatial regions (Loreau et al. 2003).

Biodiversity is declining globally despite international agreements to stem this loss. In 2002, over 150 nations signed the agreement under the Convention on Biodiversity "to achieve by 2010 a significant reduction of the current rate of biodiversity loss" (Secretariat of the Convention on Biological Diversity 2003). Recent analyses have found that, despite some notable successes, and the increasing expansion of protected areas globally, these goals are not being met nor are they expected to be met in the coming decades (Butchart et al. 2010; Secretariat of the Convention on Biological Diversity 2010; Kleijn et al. 2011; Pereira et al. 2010). Biodiversity within the United States (US) is similarly threatened, with the US Fish and Wildlife Service listing 587 animals and 794 plants as threatened and endangered in 2011 (US-Fish and
Wildlife Service (USFWS) 2011). Various analyses, including with the Globio3 model, project significant declines in biodiversity in the future, both in the US and globally, due to human activities (Alkemade et al. 2009; Secretariat of the Convention on Biological Diversity 2006; Pereira et al. 2010).

Land use change has been a major driver of losses in biodiversity, as natural areas have been converted to agricultural or urban uses, patterns of wildfires and other disturbances have been altered, and new species have been introduced into ecosystems (MEA 2005; Sala et al. 2000; McKee et al. 2004; Alkemade et al. 2009; van Oorschot et al. 2010). Land use change often results in increases in nitrogen $(\mathrm{N})$ released to the environment by increased vehicle emissions, agricultural emissions, and runoff. Increasingly, climate change and increases in reactive nitrogen $(\mathrm{Nr})$ are being recognized as significant drivers of ecosystem changes leading to biodiversity losses (MEA 2005; Rockström et al. 2009). These stressors interact in important ways that can either amplify or mitigate changes in biodiversity (Sala et al. 2000).

Historically, fluctuations in climate and nutrient availability are common in natural systems, but the magnitude of recent changes over a relatively short time period is unprecedented in the Holocene (Rockström et al. 2009). Changes in climate generally occurred over much longer time scales and over interconnected natural landscapes. Species ranges shifted accordingly, although many went extinct if migration was impeded or if extant species prevented their immigration to new habitats (Pimm et al. 1995; IPCC 2007). Under more rapid climate change, with a highly fragmented landscape, species migrations are even less likely to be successful (IPCC 2007). Changes in average precipitation and in the frequency and intensity of storms are also expected to impact biodiversity, although the effects of these factors are less well understood. The timing of biological activity, including associations with pollinators, pests, and herbivores, are also expected to change. Finally, one of the primary drivers of climate change, elevated carbon dioxide $\left(\mathrm{CO}_{2}\right)$, can have a variety of effects on biodiversity through its influence on plant growth, soil water availability, tissue stoichiometry, and trophic interactions (Reich 2009; Reich et al. 2006).

Unprecedented increases in $\mathrm{Nr}$ are also expected to drive losses in biodiversity. Nitrogen availability has historically been low in many ecosystems, limiting 
primary production (Vitousek and Howarth 1991). Against this backdrop of low $\mathrm{N}$ availability and tight recycling in undisturbed natural ecosystems, globally available $\mathrm{N}$ has increased tenfold from 1860 to the early 1990s due to industrial and agricultural activities (Galloway et al. 2004). Indeed, it is estimated that human-derived $\mathrm{Nr}$ surpassed all natural processes combined sometime around the 1980s, a trend that is projected to increase $\mathrm{Nr}$ another $70 \%$ by 2050 (Galloway et al. 2004; Vitousek et al. 1997). It follows that species distributions that evolved under largely $\mathrm{N}$-limited natural conditions are likely to have changed and will change further.

Nitrogen enrichment impacts biodiversity in a variety of ways. For plants, these are usually categorized into four mechanisms: eutrophication, acidification, direct damage, and through secondary factors (Bobbink et al. 2010; Dise et al. 2011; Pardo et al. 2011a, b). Nitrogen is a commonly limiting resource for autotrophic plants, and excess amounts can lead to eutrophication of ecosystems, thus favoring fastgrowing species in terrestrial and aquatic systems. This increased growth can reduce light penetration at the soil layer (or underwater for submerged macrophytes) and reduce belowground nutrient availability for other species, leading to overall declines in biodiversity and shifts in species composition (Hautier et al. 2009; Dise et al. 2011). Nitrogen enrichment can also acidify soil and water, lead to losses of base cations from the soil, nutrient imbalances, and increases in toxic compounds in the soil (e.g., aluminum, $\mathrm{Al}^{3+}$ ) (Dise et al. 2001), also leading to reductions in biodiversity and selection for acidtolerant species. Finally, $\mathrm{N}$ enrichment can aggravate the impact on biodiversity of secondary stressors such as fire, pests, and climate extremes (including frost and drought). Vulnerable plant communities can become more simplified in structure and less diverse in species than their undisturbed counterparts, harming animals that depend on certain plant species for food, habitat, or other resources (Dise et al. 2011; McKinney and Lockwood 1999). Biodiversity of other biota, including soil microbes, can also be directly affected by $\mathrm{Nr}$ enrichment, showing shifts in composition and reductions in beneficial populations (Johnson et al. 2003).

Nitrogen can interact with climate in several ways to affect biodiversity. Additive effects occur when $\mathrm{N}$ and climate affect biodiversity independently of one another. Interactive effects occur when the impact of one (e.g., $\mathrm{N}$ enrichment) is contingent on the effect of the other (e.g., climate change). When impacts are additive, total effects can be estimated by their sum (even though some may be positive and some negative), whereas, when impacts are interactive, total effects can lead to disturbances not anticipated from considering either separately. Compensatory (or antagonistic) effects occur when an interaction causes the combined effect of the two factors (net impact) to be dampened or offset by each other. Synergistic effects occur when an interaction causes the net impact from factors to be amplified.

In this review, we focus on how interactions between climate change and $\mathrm{N}$ enrichment influence biodiversity within the US. Our conceptual model (Fig. 1) illustrates how changing climate, $\mathrm{CO}_{2}$ and $\mathrm{N}$ can independently affect biodiversity, and also how biotic and abiotic factors can interact to influence biodiversity. Our discussion is limited by available data and information from research on these topics. As such, there is a focus on biodiversity at the scale of species, especially plants, with somewhat more information available for terrestrial systems than aquatic systems. We describe several major factors affecting biodiversity and how climate and $\mathrm{Nr}$ may interact to influence these factors (section "Introduction"), using examples from several ecosystems and taxa (section "Sensitivity of specific ecosystems to climate-N interactions"). We then discuss to the implications of this research, including evaluating risks to biodiversity from $\mathrm{Nr}$ enrichment and climate change using critical loads and other tools (section "Evaluating risks from nitrogen enrichment and climate change on biodiversity"), modeling efforts to assess climate and $\mathrm{Nr}$ interactions (section "Modeling"), and potential adaptation and mitigation efforts to reduce these interactions (section "Management and policy options for reducing impacts on biodiversity"). Lastly, we highlight some recommended areas of research (section "Summary and key research needs").

\section{Factors that determine biodiversity}

Biodiversity within a given region is determined by complex interacting abiotic and biotic controls (Gaston 2000; Ricklefs 2004), which can be influenced by anthropogenic $\mathrm{N}$ enrichment and climate change (Sala et al. 2000; Chapin III et al. 2000). A full account of the factors influencing biodiversity is beyond the 


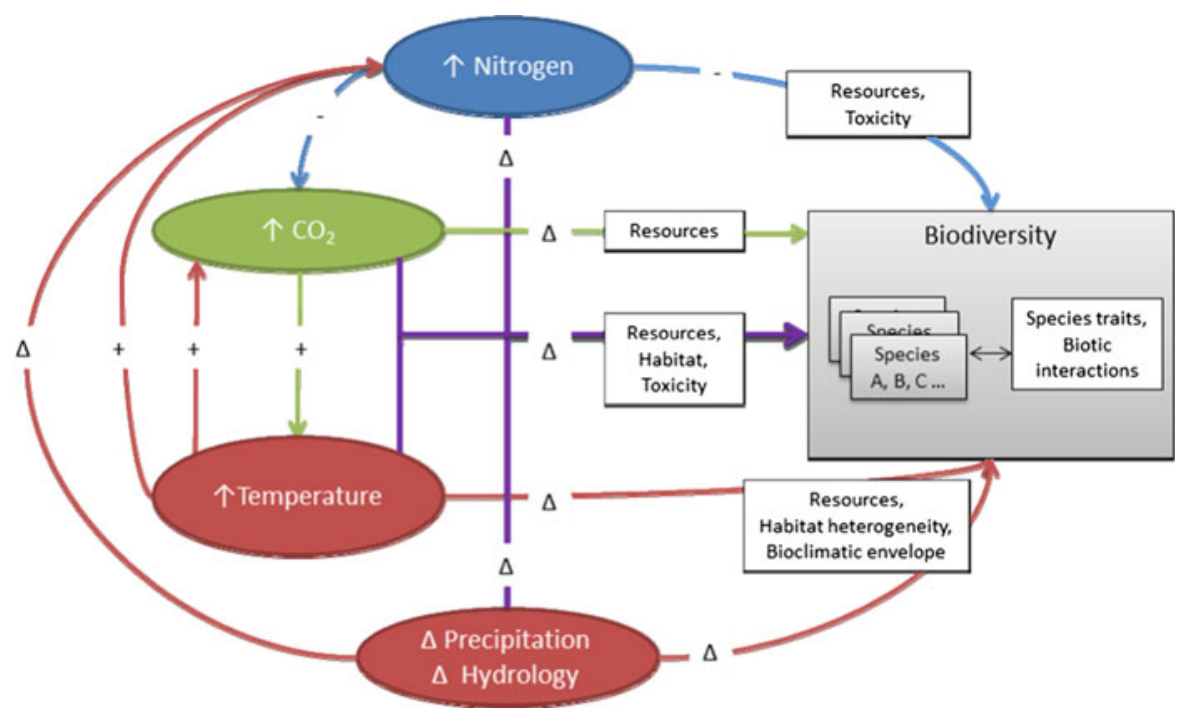

Fig. 1 Conceptual model of the direct and indirect effects of global change factors on biodiversity. Shown are effects on ecosystem biodiversity (gray box) from elevated nitrogen, elevated $\mathrm{CO}_{2}$ and climate change (elevated temperature and changes in precipitation and hydrology). Predominant direction of effect is shown as positive $(+)$, negative $(-)$ or as a possible change in either direction $(\Delta)$. Changes in nitrogen, $\mathrm{CO}_{2}$ and

scope of this review, but there are some general processes that operate in most systems for most taxa. Generally, for any particular species or individual to survive in an area, it must pass through "environmental filters" (Zobel 1997). Initial filters include the biogeographic distribution of species, and whether local dispersal occurs. Establishment within a site is determined by suitable abiotic conditions (e.g., climate), and biotic interactions that can limit (e.g., competition, predation) or enhance (e.g., presence of pollinators) the abundance of a species. The sections below describe the major factors involved in this filtering process, and how $\mathrm{N}$ enrichment and climate change can interactively influence some of these factors. In many cases, the influence of one factor accentuates the influence of the other, with the net result being greater changes (usually decreases) in biodiversity.

\section{Bioclimatic conditions}

To establish viable populations at a site, organisms must be able to physiologically withstand the range of climatic conditions present at that site, including extremes in temperature, solar radiation, and water climate can influence biodiversity (shown as red, blue and green arrows, respectively). Nitrogen and $\mathrm{CO}_{2}$ also can interact with climate to effect on biodiversity (purple lines). White boxes represent the additional factors mediating the effects on biodiversity, such as availability of other resources or species traits

availability. Climate change has and will continue to alter the range of these conditions, and the survival of species under changing conditions will depend on the pace of change and the biological attributes and phenology of individual species. Much of the available evidence for effects is based on small-scale, short-term experiments and should be interpreted with caution, since biodiversity at the landscape level may respond very differently as species redistribute under new climatic conditions.

The few controlled studies on the impact of changes in precipitation on biodiversity are largely from herbaceous communities, and are of relatively short duration (e.g., a few years). Research from Mediterranean systems (Zavaleta et al. 2003a, c) and tall-grass prairie (Collins et al. 2012) found that increased precipitation had a small positive or negligible effect, respectively, on species richness. Similar findings have been reported in China (Yang et al. 2011a, b).

A study from California shrub and grass ecosystems indicated that an increase of about $1^{\circ} \mathrm{C}$ above ambient temperature applied over 3 years had a negligible effect on biodiversity (Zavaleta et al. 2003a, c); in contrast, evidence from grasslands in China indicated a decrease with a similar increase in temperature. 
These diverging effects likely stem from differing impacts of simulated changes on other factors, such as changes in soil moisture (Zavaleta et al. 2003b; Yang et al. 2011a, b).

Extreme changes in temperature (e.g., hot periods and/or cold periods) and water availability (e.g., drought or flood) can subject populations to local extinction. If widespread population extinctions occur, the potential for species extinctions increases (Jeffries 2006; Parmesan 2006; Sinervo et al. 2010; Tilman and Haddi 1992).

Interactions with $\mathrm{N}$ and climate anthropogenic $\mathrm{N}$ input has the potential to change the capacity of species to tolerate altered climatic conditions. For example, earlier snowmelt in high elevation sites has caused earlier starts to the growing season, thus increasing the exposure of some plants to killing frosts (Inouye 2008; Fig. 2). Deposition of $\mathrm{N}$ has been associated with greater frost sensitivity in conifer species (Sheppard and Pfanz 2001), and the combination of more frequent frosts and greater plant sensitivity to those frosts can increase mortality rates. Nitrogen can also increase the capacity of species to tolerate a changing climate, for example, promoting growth and expansion of deciduous shrubs in tundra, while decreasing overall species richness (Chapin et al. 1995).Thus, in general, climate change and $\mathrm{N}$ may act synergistically or antagonistically on biodiversity, depending on system-specific and taxa-specific dynamics.

\section{Movement of species}

A species must be able to colonize new areas to expand its range, and diversity in a given habitat is strongly influenced by the number of species that can successfully disperse there (Zobel 1997). For example, remote islands generally have fewer species than mainland areas of similar size and conditions, often because of the difficulty of reaching these isolated habitats (Ricklefs 2004; Rosenzweig and Abramsky 1993; Rosenzweig 1995). Dispersal may limit diversity even in non-isolated areas: for example, the addition of seeds to some plant communities often leads to increases in diversity (Foster and Tilman 2003; Hubbell 2001; Hurtt and Pacala 1995).

Interactions with $N$ and climate the successful movement of species across landscapes is a complex process, including reproduction (for sessile organisms like plants), dispersal, and establishment in a new habitat. Climate change and $\mathrm{N}$ enrichment can alter each of these steps and thus expand or contract the potential range of a species. Overall declines in plant diversity associated with anthropogenic $\mathrm{N}$ deposition, described primarily in grasslands (Stevens et al. 2004, 2010; Clark and Tilman 2008; Dupré et al. 2010; Maskell et al. 2010), will affect dispersal and establishment by decreasing the pool of plant species available to migrate and form new communities as climate change occurs. And although $\mathrm{N}$ enrichment tends to increase seed production and nutritional quality in plants (Throop and Lerdau 2004), species may respond differently. For example, in Minnesota, elevated $\mathrm{N}$ increased seed production for $\mathrm{C}_{4}$ herbaceous species, and decreased seed production for $\mathrm{C}_{3}$ species (HilleRisLambers et al. 2009). In addition, elevated $\mathrm{CO}_{2}$ has also been found to increase seed production for many crop and annual species (Ackerly and Bazzaz 1995; Jablonski et al. 2002; Huxman et al. 1999), although other studies suggest that perennial species and undomesticated species may respond differently (Jablonski et al. 2002; Thurig et al. 2003; HilleRisLambers et al. 2009).

Because of these complexities, and because few experiments have examined the effects of global change on reproduction and dispersal, there is little detailed information on how ecosystems will shift with climate in the US or globally. Most modeling efforts assume that species ranges will shift with climate, though researchers acknowledge this is only a first approximation (Guisan and Thuiller 2005; Pereira et al. 2010).

\section{Disturbance}

Disturbance, or physical alteration of the habitat, plays an important role for biodiversity at the local and landscape scales. Both the frequency and intensity of disturbance are important. Areas that are either frequently or infrequently disturbed often have lower levels of biodiversity than areas with a moderate amount of disturbance. For example, rivers that experience high levels of flow variability have, in general, reduced food chain length and fewer numbers of species (Sabo et al. 2010). Disturbances influenced by climate, including fires, severe storms, and floods, are expected to change over the next century, although all are anticipated to occur more frequently and be more intense (Karl et al. 2009). 

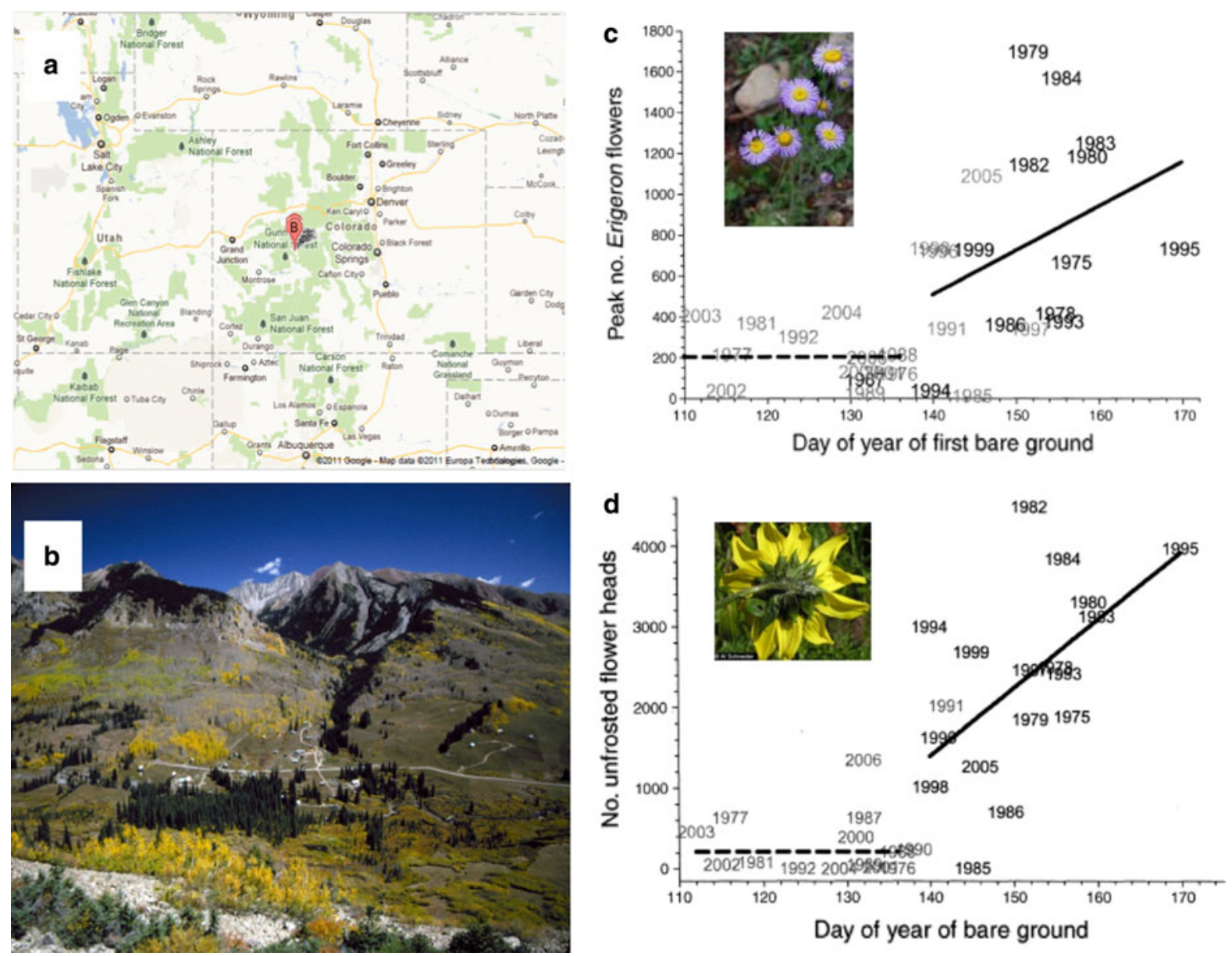

Fig. 2 Results from a study in Colorado on the effects of changes in climate on wildflower reproduction. The study location and photo (a, b; photo courtesy of David Inouye), the Rocky Mountain Biological Laboratory. The peak number of

Interactions with $N$ and climate nitrogen enrichment has the potential to alter the response of ecological communities to climate change-driven disturbance. As an example, $\mathrm{N}$ enrichment and changes in precipitation patterns in the Mojave Desert have been implicated in the success of invasive annual grasses, which increase fuel loadings and carry fires in a native shrub community not well adapted to fire (Rao et al. 2010; Fig. 3). Similarly, increased fire frequencies in chaparral vegetation, in combination with greater $\mathrm{N}$ availability, enhances the replacement of native shrubs with weedy non-native annual grasses (Haidinger and Keeley 1993). Elevated N inputs can shift allocation of plant biomass from belowground to

wildflowers (Erigeron speciosus) was lower when the season started earlier (c), and more flower heads were killed (Helianthella quinquenervis,) by frost (d) (modified from Inouye 2008)

aboveground, which tends to reduce the stabilizing influence of belowground biomass on the soil (Adair et al. 2009). Conversely, more aboveground biomass coverage can reduce the impact of rain droplets on destabilizing soil, and provide a physical barrier to storm flows in and along riverbanks, thereby reducing the potential for landslides and flooding (Korner 2004).

\section{Hydrology}

Climate change is anticipated to increase the duration of low flow periods in streams and rivers and the frequency of extreme events (e.g., drought and flood) 

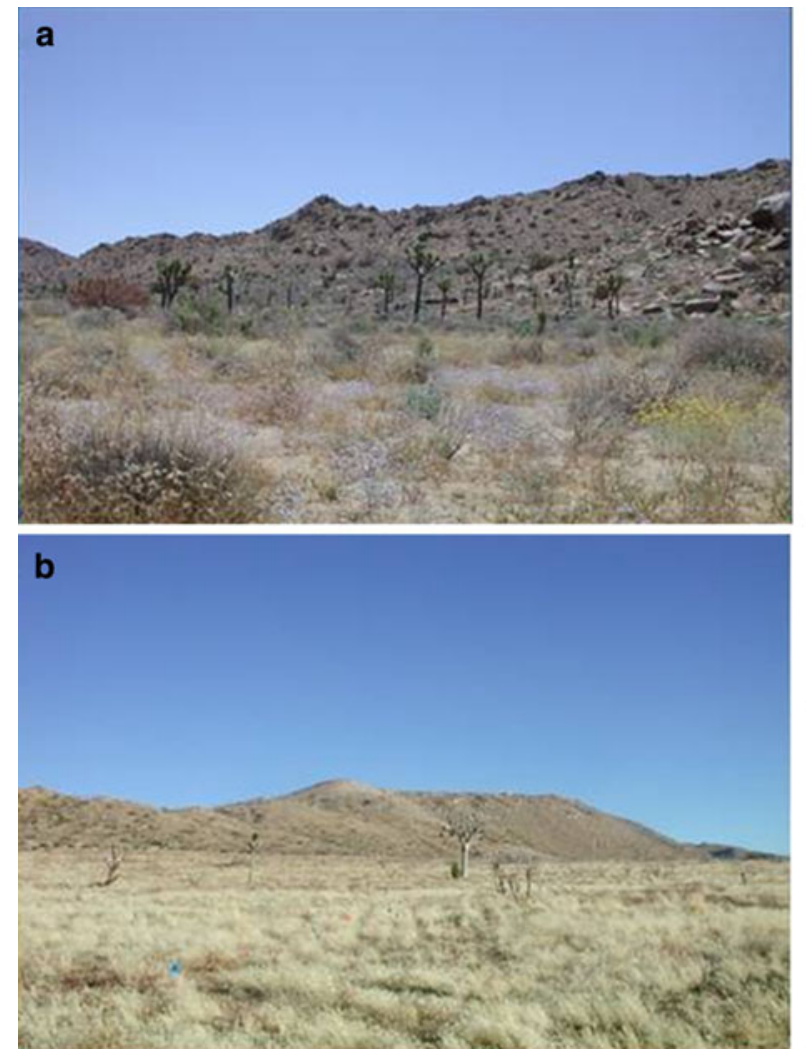

Fig. 3 The interactive effects of nitrogen $(\mathrm{N})$ and climate on the probability of fire in the Mojave Desert, CA. N deposition facilitates the growth of invasive grasses in the spaces historically bare between shrubs (low invasion and high invasion/post-fire in (a) and (b) respectively; photos courtesy

across much of the planet (IPCC 2007). During the twentieth century approximately half of the world's wetlands have disappeared (Zedler et al. 2001), and freshwater extraction in some regions is so extreme that some major rivers, including the Nile, Yellow, and Colorado Rivers, no longer flow to the sea either seasonally or entirely (MEA 2005). Climate change will alter the delivery of water to many areas by affecting how much rain falls versus snow, changes in snowmelt timing and also changes in water flows to estuaries and coastal zones.

Interactions with $N$ and climate in alpine lakes, altered snowmelt timing and increases in glacial melting can increase nutrient loading and alter lake diatom communities (Saros et al. 2010). Storms and increases in precipitation increase nutrient loads to coastal zones, and droughts increase residence times,
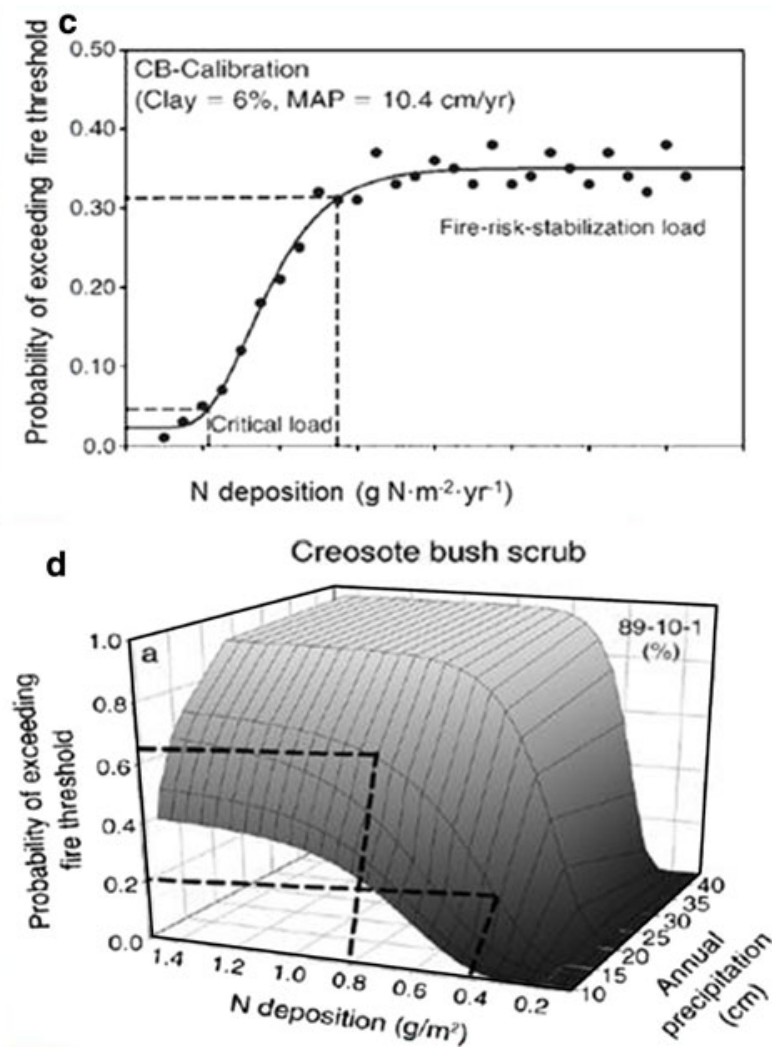

of Dr. Edith Allen). c Fire risk increasing in the creosote bush scrub community (CB) as N deposition increases; MAP is mean annual precipitation. $\mathbf{d}$ The probability of fire is enhanced with $\mathrm{N}$ deposition and increased precipitation (c, $\mathbf{d}$ adapted from Rao et al. 2010)

promoting algal growth, including growth of harmful cyanophytes and bloom-forming flagellates (Paerl and Scott 2010). Altered hydrology can cause wholesale shifts in habitat, and if areas dry up, can cut off connectivity in streams or reduce habitat in wetlands.

\section{Resource supply}

The supply of resources (e.g., water, light, nutrients) is an important control on biodiversity. The supply of $\mathrm{N}$ in many ecosystems is restricted by climatic factors that constrain the turnover of organic matter, including low soil temperature and both high and low soil moisture (Hobbie 1996). Studies across major biomes have found that, in general, increased biodiversity is associated with increased fertility and productivity which is positively correlated with soil $\mathrm{N}$ content 
(Chase and Leibold 2002; Waide et al. 1999). However, in more focused investigations of terrestrial and marine ecosystems and some fresh water ecosystems, diversity has been found to be inversely correlated with $\mathrm{N}$ inputs (Stevens et al. 2004, 2010, Clark and Tilman 2008; National Research Council 2000; Dudgeon et al. 2006). Thus, it appears to be the interplay of resource supply with other factors such as dispersal, scale, species interactions, and others that determine the net effect of resource supply on biodiversity.

Interactions with $N$ and climate climate change may increase $\mathrm{N}$ availability in many ecosystems, potentially enhancing the effect of additional $\mathrm{N}$ enrichment on changes in diversity. For example, melting alpine glaciers are releasing $\mathrm{Nr}$ into receiving streams and lakes, where increasing $\mathrm{N}$ has been linked to shifts in diatom species assemblages from oligotrophic to mesotrophic species (Saros et al. 2010; Baron et al. 2009; Wolfe et al. 2001). Warming increases $\mathrm{N}$ mineralization in soils, increasing $\mathrm{N}$ availability in peat bogs (Keller et al. 2004; Weedon et al. 2012), subarctic heath-lands (Hartley et al. 1999), and a New England forest (Butler et al. 2011). In tundra, greater shrub cover promoted by $\mathrm{N}$ enrichment can enhance the development of an earlier insulating snow cover, increasing decomposition during the winter and thus the supply of plant-available $\mathrm{N}$ (Sturm et al. 2005). Elevated $\mathrm{CO}_{2}$, on the other hand, may decrease $\mathrm{N}$ supply to plants due to shifts in the balance of $\mathrm{C}$ and $\mathrm{N}$ causing a slowdown in decomposition (Hu et al. 2001).

\section{Species interactions: consumptive and non-consumptive}

Species interactions, including non-consumptive functions such as competition and facilitation, and consumptive processes such as herbivory, parasitism, and predation, can influence the success or failure of species within a community, and subsequently influence its biodiversity (Ricklefs 1987). The spatial and temporal extent, intensity, and outcome of these interactions often depend on the climatic conditions and variations in the supply of resources such as $\mathrm{N}$.

Interactions with $\mathrm{N}$ and climate competition for $\mathrm{N}$ by autotrophs could decrease under climate warming and $\mathrm{N}$ enrichment scenarios by shifting the limiting resource(s) from $\mathrm{N}$ to phosphorus $(\mathrm{P})$ in aquatic systems (Elser et al. 2009), and P, light, or water in terrestrial systems (Hautier et al. 2009). However, the overall intensity of competition could increase as well. In California, simulated elements of a global change scenario (elevated $\mathrm{N}$ deposition, temperature, $\mathrm{CO}_{2}$, and precipitation) influenced diversity, as measured by total grasslands species richness, in different ways. For example diversity increased with elevated precipitation alone, was unaffected by elevated temperature alone, and decreased with increasing $\mathrm{N}$ and temperature (Zavaleta et al. 2003a, c). All factors in combination caused changes in the relative dominance of forbs and grasses, with decreases in forb abundance. Forbs make up most of the plant biodiversity in these systems (Fig. 4a, b). Elevated $\mathrm{N}$ and $\mathrm{CO}_{2}$ reduced the difference in flowering date between the two groups, increasing temporal overlap and leading to greater overall competition between these two functional groups, with the grasses subsequently dominating (Fig. 4c). The highly invasive yellow starthistle, Centaurea solstitialis L., also benefited disproportionately under altered climate and $\mathrm{N}$ regimes (Fig. 4d). However, the only other experiment examining the impact of both elevated $\mathrm{N}$ and $\mathrm{CO}_{2}$ on biodiversity in the US (Reich 2009), found that, although $\mathrm{N}$ addition reduced diversity in a Minnesota grassland over 10 years $(-16 \%)$, elevated $\mathrm{CO}_{2}$ mitigated about half of this loss. Thus, although elevated $\mathrm{N}$ reduces biodiversity in general, other global change factors may interact to affect this response.

Climate change and $\mathrm{N}$ enrichment may have an additive effect on increasing the amount of consumption and population growth of consumers (e.g., herbivores, carnivores, etc.). Greater consumption rates can increase diversity when a dominant competitor is the preferred target species, or decrease diversity when rare species are preferentially consumed (Olff and Ritchie 1998). Many consumers, particularly herbivores, are growth-limited by the supply of N (Mattson 1980). Growth may increase substantially in response to $\mathrm{N}$ enrichment as forage quality increases with higher $\mathrm{N}$ concentrations in plants, lower concentrations of defensive compounds, and shifts to higher dominance of more palatable species (Throop and Lerdau 2004). Climate change in temperate and arctic climates will benefit many invertebrate consumers due to a longer growing season (Bale et al. 2002) that allows some insect herbivore species to complete more than one life cycle in a year (Roy et al. 2009; Mitton and Ferrenberg 
a
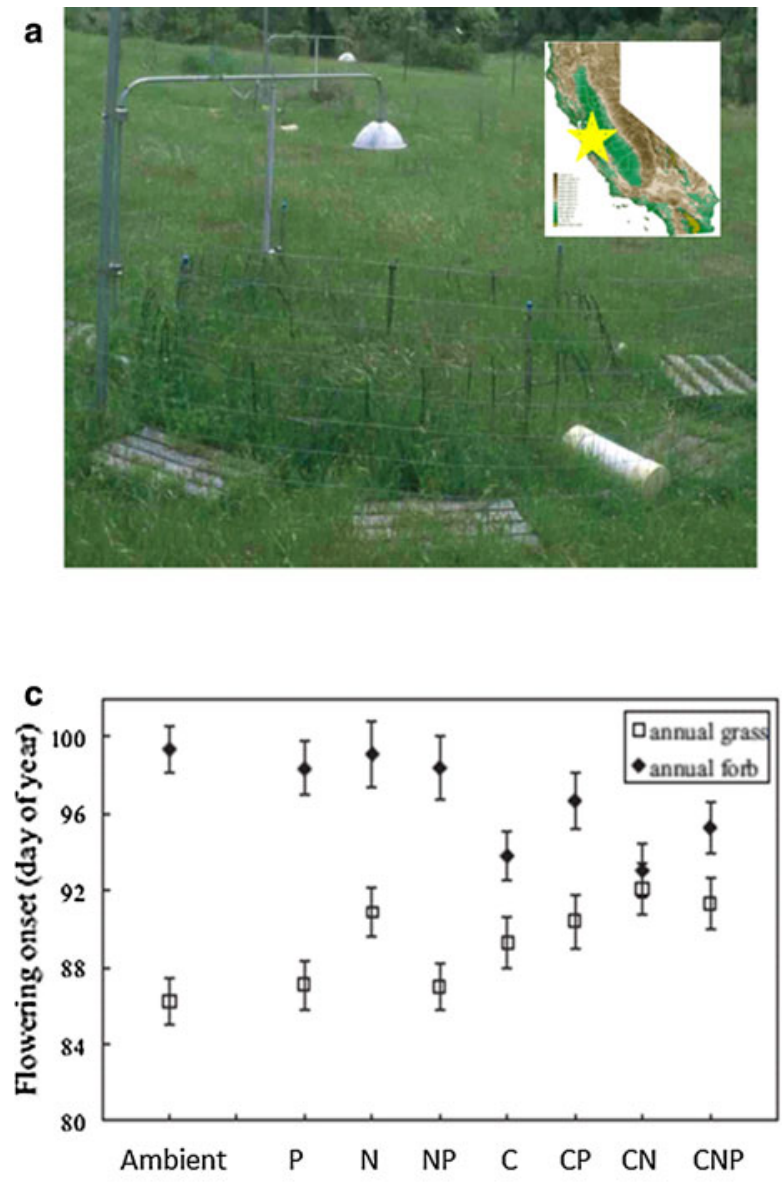

Fig. 4 Results from a global change experiment in California on the individual and interactive effects on plant diversity from four global change factors (elevated temperature $(\mathrm{T})$, precipitation $(\mathrm{P})$, nitrogen $(\mathrm{N})$, and $\mathrm{CO}_{2}$ concentrations $(\mathrm{C})$; Shaw et al. 2002; Zavaleta et al. 2003a; Cleland et al. 2007, Dukes et al. 2011). a A typical plot and the geographic location of the experiment (modified from Shaw et al. 2002). Results of the

2012). The longer growing season is implicated as one factor contributing the outbreak of mountain pine beetles in western North America (Raffa et al. 2008; Bentz et al. 2010).

\section{Habitat heterogeneity}

Generally speaking, more heterogeneous habitats, or areas with many different kinds of habitats, can support more species (Ricklefs 2004). For example, mixed forest stands usually support more species than single-species stands, and old growth forests more species than mixed stands.
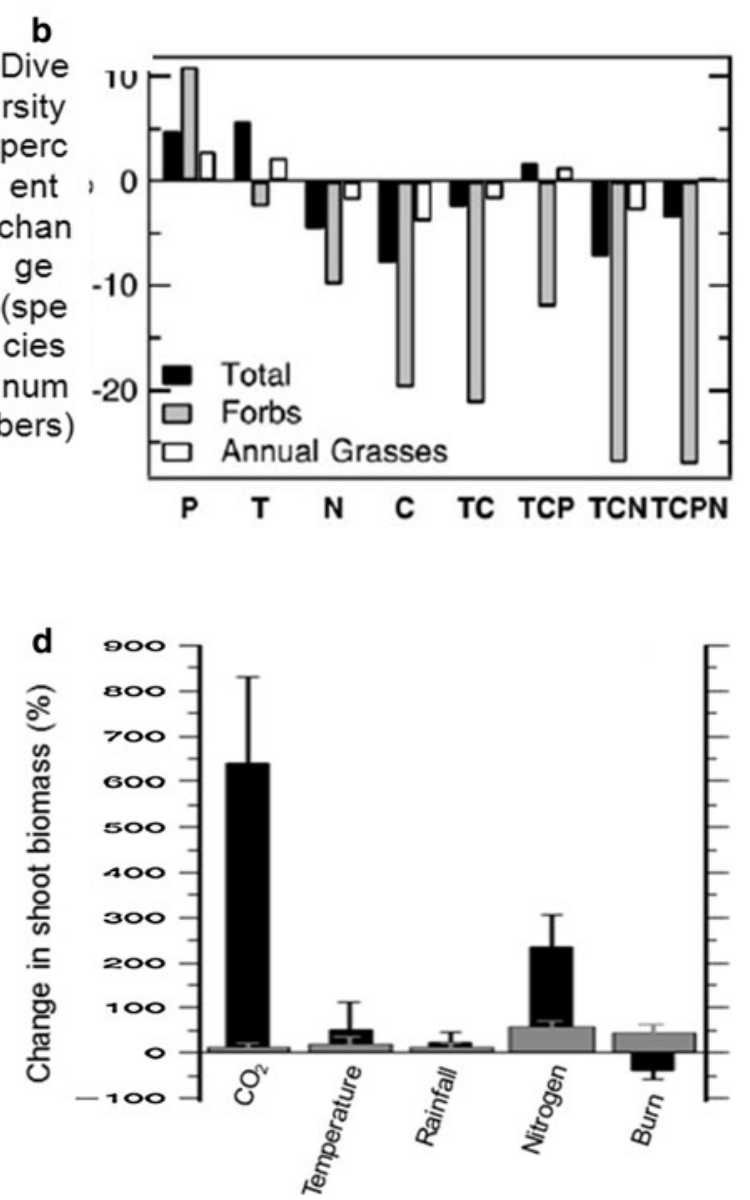

overall diversity changes are shown in (b) (Zavaleta et al. 2003a) related to individual and combined treatments. Shifts in phenology for annual grasses and forbs are shown in (c) (Cleland et al. 2006, Copyright 2006 National Academy of Sciences, USA). Responses of the invasive star thistle (thin black bars) and the extant community (thick grey bars) are shown in (d) (Dukes et al. 2011)

Interaction of $N$ and climate some species preferentially benefit from increases in $\mathrm{N}$, leading to an overall simplification of the habitat. This is often termed "biotic homogenization" and can be driven by a number of factors such as the spread of few numbers of invasive species (McKinney and Lockwood 1999). In terrestrial ecosystems $\mathrm{N}$ deposition can reduce local variation in soil $\mathrm{N}$ availability, which is an important contributor to diversity (Gilliam 2006). In grasslands $\mathrm{N}$-addition experiments, reductions in plant diversity led to a reduction in the diversity of insects (Haddad et al. 2000). Climate change may exacerbate this simplification, both through its effects on species diversity and habitat diversity. 


\section{Sensitivity of specific ecosystems to climate-N interactions}

Reviewing the interactions between $\mathrm{N}$ and climate change is challenging since many studies address these impacts individually rather than together. Few manipulation experiments alter temperature or precipitation and nutrient availability; fewer still examine the impacts on biodiversity. Reich et al. (2006) reviewed all known studies combining $\mathrm{N}$ enrichment and elevated $\mathrm{CO}_{2}$ treatments, and found only eight that they considered representative of natural responses (e.g., fieldbased, replicated, long term), with none in mature mixed forests. Globally, the Jasper Ridge FACE experiment in Stanford, California (Shaw et al. 2002) is the only field experiment examining the impact on biodiversity of increasing $\mathrm{N}$ deposition, temperature, $\mathrm{CO}_{2}$, and precipitation, both singly and in combination. Clearly there is growing recognition of the importance of these interactions, and a need for more information. Complementary approaches exist, however, such as modeling, regional gradient surveys, and re-surveys or retrospective analyses of existing long-term data sets. Evidence for single factor and interactive effects by ecosystem is shown in Table 1; detailed information and case studies by region are summarized in the Supplementary table. In this section we use this combined evidence to examine the sensitivity of different ecosystems and regions to changes in $\mathrm{N}$ and climate. Section "Evaluating risks from nitrogen enrichment and climate change on biodiversity" will integrate this knowledge with future projections of $\mathrm{N}$ deposition and climate to explore risk and vulnerability.

\section{Forests}

Some forest ecosystems are sensitive to the interactions between $\mathrm{N}$ and climate change, and many of the interactions are synergistic. Anthropogenic increases in $\mathrm{N}$ loading to forests are mainly via atmospheric deposition, and thus regions with higher $\mathrm{N}$ deposition are more at risk (see section "Evaluating risks from nitrogen enrichment and climate change on biodiversity" for more specific discussions of risk and vulnerability). Across the Northeastern US, higher $\mathrm{N}$ deposition is associated with enhanced tree growth for most species (Thomas et al. 2010). Nitrogen loading preferentially affects certain species as a consequence of species traits, and in some cases alters the bioclimatic envelope of these species, causing them to be more sensitive to climate change. For example, increased $\mathrm{N}$ stimulates leaf area growth, which has been speculated to reduce drought resistance (McNulty and Boggs 2010). Increased N deposition also contributes to soil acidification and subsequent loss of base cations, including calcium. Decreased calcium availability can compromise plant cell membrane integrity, thereby decreasing cold tolerance and increasing the potential for freezing injury (DeHayes et al. 1999; Schaberg et al. 2002). Thus $\mathrm{N}$ and climate change interact to alter species composition through drought or frost damage, driven by the plants' response to increased $\mathrm{N}$.

Moreover, much of the biodiversity of forests is in the understory herb and shrub layer rather than in the overstory tree layer (Gilliam 2006). These taxa are poorly studied in the literature, but sensitivity to $\mathrm{N}$ deposition and interactions with climate change are likely (Gilliam 2006; Wu and Driscoll 2010).

\section{Tundra}

In the Arctic, warming has contributed to dramatic increases in shrub cover, as documented by aerial photographs at thousands of locations between the Brooks Range and the Arctic Coast in 1948-1950 and later in 1999-2000 (Sturm et al. 2001). This has led to a shift in community type from more open graminoid ecosystems to areas dominated by shrubs. Experiments at the Toolik Lake Arctic LTER site confirmed that elevated temperature enhanced shrub production and reduced production of non-vascular plants. Elevated $\mathrm{N}$ increased growth and production of deciduous shrubs but reduced growth of evergreen shrubs and non-vascular plants, while combined $\mathrm{N}$ and temperature treatments reduced species richness 30-50\% due to loss of less abundant species (Chapin et al. 1995).

Grasslands

Grasslands are likely to be especially sensitive to changes in $\mathrm{N}$ and climate for many reasons. Compared with forests, grasslands are dominated by plants that have a strong capacity for rapid changes in growth (Knapp and Smith 2001). Grasslands are often limited by $\mathrm{N}$ availability, or co-limited by $\mathrm{N}$ and other resources such as water or $\mathrm{P}$ (Elser et al. 2007; Hooper and Johnson 1999; LeBauer and Treseder 2008). 
Table 1 Impacts of nitrogen, climate and nitrogen-climate ( $\mathrm{NxCC}$ ) interactions for major ecosystems in the US

\begin{tabular}{|c|c|c|c|c|c|}
\hline Ecosystem & $\begin{array}{l}\text { Major Impacts of Climate } \\
\text { Change } \\
\text { (NCA 2009) }\end{array}$ & Major impacts of $\mathrm{N}$ & Nitrogen references & Impacts of $\mathrm{NxCC}$ & $\begin{array}{l}\mathrm{NxCC} \\
\text { References }\end{array}$ \\
\hline Tundra & $\begin{array}{l}\text { More rapid climate change that } \\
\text { rest of US, longer growing } \\
\text { season, permafrost warming, } \\
\text { changes in soil temperature } \\
\text { and moisture, increased fire }\end{array}$ & $\begin{array}{l}\text { Increased productivity, shifts } \\
\text { towards graminoids and } \\
\text { shrubs from bryophytes and } \\
\text { lichens, increased } \\
\text { decomposition }\end{array}$ & $\begin{array}{l}\text { Shaver et al. (1998), } \\
\text { Nowinski et al. (2008), } \\
\text { Arens et al. (2008), van } \\
\text { Wijk et al. (2004), } \\
\text { Cornelissen et al. (2001) }\end{array}$ & $\begin{array}{l}\text { Additive-both increase } \mathrm{N} \\
\text { availability, warming } \\
\text { increases nitrogen } \\
\text { mineralization, increasing } \\
\text { shrubs trap more snow, } \\
\text { wetness decreases } \\
\text { sensitivity to } \mathrm{N}\end{array}$ & \\
\hline Taiga & $\begin{array}{l}\text { More rapid climate change that } \\
\text { rest of US, Increase in pest } \\
\text { outbreaks and fire, Longer } \\
\text { growing season, permafrost } \\
\text { warming and forest declines, } \\
\text { changes in soil temperature } \\
\text { and moisture, increased fire } \\
\text { frequency increases, drier } \\
\text { soils }\end{array}$ & $\begin{array}{l}\text { Increased decomposition, shift } \\
\text { in species composition (from } \\
\text { shrubs to grasses; lichen } \\
\text { community composition) }\end{array}$ & $\begin{array}{l}\text { Aerts and Chapin, (2000), } \\
\text { Gough et al. (2000), } \\
\text { Nordin et al. (2005), Geiser } \\
\text { and Nadelhoffer (2011) }\end{array}$ & $\begin{array}{l}\text { Increasing temperature and } \\
\mathrm{N} \rightarrow \text { increase in green } \\
\text { algae }\end{array}$ & \\
\hline Alpine & $\begin{array}{l}\text { Shorter duration of snowpack, } \\
\text { longer growing season, } \\
\text { increased exposure to } \\
\text { freezing events, movement } \\
\text { of invasive species into } \\
\text { alpine area }\end{array}$ & $\begin{array}{l}\text { Alteration of species, } \\
\text { decreased diversity and } \\
\text { whole community } \\
\text { composition }\end{array}$ & $\begin{array}{l}\text { Bowman et al. (2006), } \\
\text { Bowman and Steltzer } \\
(1998)\end{array}$ & $\begin{array}{l}\text { Additive - warming will } \\
\text { increase nutrient supply, } \\
\text { greater species pool } \\
\text { combined with higher } \mathrm{N} \\
\text { makes it a more inevasible } \\
\text { system }\end{array}$ & \\
\hline $\begin{array}{l}\text { Conifer } \\
\text { forests }\end{array}$ & $\begin{array}{l}\text { Southeast-longer growing } \\
\text { seasons, hotter summers and } \\
\text { drought; reduced forest } \\
\text { production under drought, } \\
\text { reduced snowpack, increased } \\
\text { fire, pest outbreaks, } \\
\text { hurricanes and flooding; } \\
\text { range shifts }\end{array}$ & $\begin{array}{l}\text { Shifts in understory herbaceous } \\
\text { species composition, shifts in } \\
\text { microbial assemblages }\end{array}$ & $\begin{array}{l}\text { Thomas et al. (2010), } \\
\text { Lilleskov et al. (2008) }\end{array}$ & $\begin{array}{l}\text { Synergistic-N deposition } \\
\text { and productivity (C } \\
\text { sequestration)-species } \\
\text { specific; drought, elevated } \\
\text { tissue } \mathrm{N} \text { and pest } \\
\text { susceptibility, } \mathrm{N} \text { increases } \\
\text { susceptibility to disease, to } \\
\text { abiotic stresses } \rightarrow \text { shifts in } \\
\text { species composition }\end{array}$ & $\begin{array}{l}\text { McNulty } \\
\text { and } \\
\text { Boggs } \\
(2010)\end{array}$ \\
\hline $\begin{array}{l}\text { Hardwood } \\
\text { forests }\end{array}$ & $\begin{array}{l}\text { Northeast-longer growing } \\
\text { seasons, hotter summers and } \\
\text { drought; increased fire, ice } \\
\text { storm, heavy precipitation, } \\
\text { extreme events, flooding, } \\
\text { reduced extent and duration } \\
\text { of snowpack, increased } \\
\text { exposure to soil freezing } \\
\text { events, range shifts }\end{array}$ & $\begin{array}{l}\text { Shifts in understory herbaceous } \\
\text { species composition, shifts in } \\
\text { microbial assemblages }\end{array}$ & $\begin{array}{l}\text { Thomas et al. (2010), Gilliam } \\
\text { (2006), Hurd et al. (1998) }\end{array}$ & $\begin{array}{l}\mathrm{N} \text { dep and productivity (C } \\
\text { sequestration)—-species } \\
\text { specific; drought, elevated } \\
\text { tissue } \mathrm{N} \text { and pest } \\
\text { susceptibility, } \mathrm{N} \text { increases } \\
\text { susceptibility to disease, to } \\
\text { abiotic stresses } \rightarrow \text { shifts in } \\
\text { species composition }\end{array}$ & $\begin{array}{l}\text { Halman } \\
\text { et al. } \\
\text { (2011) }\end{array}$ \\
\hline Grasslands & $\begin{array}{l}\text { Longer growing season, } \\
\text { warmer, wetter } \rightarrow \text { greater } \\
\text { biomass production, } \\
\text { potential for increased fire } \\
\text { intensity, impacts on } \\
\text { dispersal because of prior } \\
\text { fragmentation, range shifts, } \\
\text { spread of pests and weeds }\end{array}$ & $\begin{array}{l}\text { Compositional shifts towards } \\
\text { fast-growing (often C3) } \\
\text { grasses, structurally } \\
\text { simplified, increased } \\
\text { competition for light, alter } \\
\text { microbial assemblages, } \\
\text { reduced insect diversity and } \\
\text { shift towards generalists }\end{array}$ & $\begin{array}{l}\text { Tilman (1993), Wedin and } \\
\text { Tilman (1996), Clark and } \\
\text { Tilman (2008) }\end{array}$ & $\begin{array}{l}\text { Warmer, wetter } \rightarrow \text { intensify } \\
\mathrm{N} \text { limitation (which could } \\
\text { lead to a greater impact if } \\
\text { soil } \mathrm{N} \text { availability is low or } \\
\text { a smaller impact if soil } \mathrm{N} \\
\text { availability increases with } \\
\mathrm{CC} \text {, reduce water } \\
\text { limitation), interaction of } \\
\text { elevated } \mathrm{CO}_{2}+\mathrm{N} \text { may } \\
\text { reduce species loss from } \\
\text { elevated } \mathrm{N} \text { input alone }\end{array}$ & $\begin{array}{l}\text { Knapp et al. } \\
(1993, \\
1996 \\
1998)\end{array}$ \\
\hline Deserts & $\begin{array}{l}\text { Reductions in water supply. } \\
\text { increased temperature, } \\
\text { drought, fire and invasive } \\
\text { species will affect the } \\
\text { landscape }\end{array}$ & $\begin{array}{l}\text { Alterations in species } \\
\text { composition, increases in } \\
\text { exotic species biomass, } \\
\text { decrease in native species }\end{array}$ & $\begin{array}{l}\text { Allen et al. (2009), Rao and } \\
\text { Allen (2010), Rao et al. } \\
\text { (2010) }\end{array}$ & $\begin{array}{l}\text { Increased } \mathrm{N} \text { deposition } \\
\text { leading to increased } \\
\text { biomass accumulation, } \\
\text { increasing fire frequency }\end{array}$ & $\begin{array}{l}\text { Brooks et al. } \\
(2004), \\
\text { Brooks } \\
\text { and } \\
\text { Minnich } \\
(2006)\end{array}$ \\
\hline
\end{tabular}


Table 1 continued

\begin{tabular}{|c|c|c|c|c|c|}
\hline Ecosystem & $\begin{array}{l}\text { Major Impacts of Climate } \\
\text { Change } \\
\text { (NCA 2009) }\end{array}$ & Major impacts of $\mathrm{N}$ & Nitrogen references & Impacts of NxCC & $\begin{array}{l}\text { NxCC } \\
\text { References }\end{array}$ \\
\hline Shrubland & $\begin{array}{l}\text { Decreased precipitation, } \\
\text { increased temperature, more } \\
\text { storms, increased fire. } \\
\text { Increased die-off of pinyon } \\
\text { pine and alteration of pine- } \\
\text { rich biodiversity hot spots. } \\
\text { Range shifts, spread of } \\
\text { invasive species }\end{array}$ & $\begin{array}{l}\mathrm{N} \text { addition decreasing soil } \\
\text { moisture in sagebrush } \\
\text { steppe. Air quality in the } \\
\text { southwest expected to } \\
\text { decline. Ozone and other } \\
\text { pollutants can impact these } \\
\text { ecosystems. Increase in } \\
\text { invasive species, decrease in } \\
\text { shrub cover and native } \\
\text { species. }\end{array}$ & $\begin{array}{l}\text { Inouye (2006), Fenn et al. } \\
\text { (2010) }\end{array}$ & $\begin{array}{l}\text { NxCC may interact to lead to } \\
\text { even drier soils and } \\
\text { increased fire }\end{array}$ & \\
\hline Wetlands & $\begin{array}{l}\text { Intense droughts in the } \\
\text { northeast and especially } \\
\text { southeast, leading to local or } \\
\text { global extinctions, flooding } \\
\text { and sea level rise, decline in } \\
\text { dissolved oxygen leading to } \\
\text { loss of aquatic species }\end{array}$ & $\begin{array}{l}\text { Nitrogen generally increases } \\
\text { production and decreases } \\
\text { diversity, particularly in high } \\
\mathrm{N} \text { load setting like coastal } \\
\text { zone (sea grass decline); } \\
\text { invasion of non-native } \\
\text { species, altered competition, } \\
\text { loss of N-sensitive species } \\
\text { like eelgrass }\end{array}$ & $\begin{array}{l}\text { Aldous (2002), Bedford et al. } \\
\text { (1999), Darby and Turner } \\
\text { (2008a, b), Mendelssohn } \\
\text { (1979), Tyler et al. (2007), } \\
\text { Wigand et al. (2003), Tyler } \\
\text { et al. (2007), Crain (2007), } \\
\text { Mendelssohn (1979), } \\
\text { Wigand et al. (2003), } \\
\text { Latimer and Rego (2010) }\end{array}$ & $\begin{array}{l}\text { Drying and increases in } \\
\text { anthropogenic nitrogen will } \\
\text { together strongly alter and } \\
\text { likely reduce biodiversity. } \\
\text { In freshwater wetlands, } \mathrm{N} \\
\text { inputs increase } \mathrm{CH}_{4} \text { and } \\
\mathrm{N}_{2} \mathrm{O} \text { production }\end{array}$ & $\begin{array}{l}\text { Liu and } \\
\text { Greaver } \\
(2009)\end{array}$ \\
\hline Lakes & $\begin{array}{l}\text { Lakes are projected to shrink } \\
\text { and become less connected } \\
\text { with warming and } \\
\text { decreasing flow; so less } \\
\text { habitat aquatic habitat } \\
\text { overall (happening quickly } \\
\text { in Alaska where migrating } \\
\text { birds are at risk). Decreases } \\
\text { in extent and duration of lake } \\
\text { ice; snowmelt changes and } \\
\text { extreme events increase. } \\
\text { Residence times and } \\
\text { turnover may change as well } \\
\text { leading to more intense } \\
\text { stratification and fish kills. }\end{array}$ & $\begin{array}{l}\text { In N-limited systems, } \\
\text { productivity increases, } \\
\text { diatom communities are } \\
\text { altered; hypoxia will have } \\
\text { even more pronounced } \\
\text { impacts on biodiversity }\end{array}$ & Kelly et al. (2011) & $\begin{array}{l}\text { NxCC driven shifts in } \\
\text { composition and } \\
\text { productivity, possible } \\
\text { eutrophication and hypoxia }\end{array}$ & $\begin{array}{l}\text { Kelly et al. } \\
\text { (2011) }\end{array}$ \\
\hline Streams & $\begin{array}{l}\text { River networks may shrink and } \\
\text { become less connected with } \\
\text { warming and decreasing } \\
\text { flow; so less habitat aquatic } \\
\text { habitat overall. Reductions in } \\
\text { snowpack alter runoff } \\
\text { timing. Salmon and other } \\
\text { coldwater species will } \\
\text { experience additional } \\
\text { stresses from temperature. } \\
\text { Increases in extreme events } \\
\text { such as flooding will also } \\
\text { affect biodiversity and } \\
\text { trophic structure. }\end{array}$ & $\begin{array}{l}\text { In } \mathrm{N} \text {-limited systems, } \\
\text { eutrophication and } \\
\text { subsequent alteration of } \\
\text { species composition; } \\
\text { hypoxia will have even more } \\
\text { pronounced impacts on } \\
\text { biodiversity }\end{array}$ & $\begin{array}{c}\text { Rahel and Olden (2008), } \\
\text { Baron et al., this issue }\end{array}$ & $\begin{array}{l}\text { NxCC driven shifts in } \\
\text { composition and } \\
\text { productivity, possible } \\
\text { eutrophication and hypoxia }\end{array}$ & $\begin{array}{l}\text { Hobbs et al. } \\
\text { (2010), } \\
\text { Baron } \\
\text { et al., this } \\
\text { issue }\end{array}$ \\
\hline $\begin{array}{l}\text { Estuarine } \\
\text { and } \\
\text { Near- } \\
\text { Coastal } \\
\text { Ocean }\end{array}$ & $\begin{array}{l}\text { Changes in flow amount and } \\
\text { timing, and estuarine } \\
\text { residence time and turnover } \\
\text { impact species composition. } \\
\text { Ocean acidification. Sea } \\
\text { level rise is eroding } \\
\text { shorelines. Reduced sea ice } \\
\text { in Alaska alters blooms and } \\
\text { fish stocks. Displaced marine } \\
\text { species and shifts. Changes } \\
\text { in currents may increase } \\
\text { extent and duration of } \\
\text { northern Pacific Dead zone }\end{array}$ & $\begin{array}{l}\mathrm{N} \text { drives eutrophication in } \\
\text { many coastal systems, } \\
\text { affecting structure and } \\
\text { biodiversity }\end{array}$ & $\begin{array}{l}\text { Gilbert et al. (2005), Howarth } \\
\text { et al. (2011) }\end{array}$ & $\begin{array}{l}\text { NxCC driven eutrophication } \\
\text { and hypoxia; } \\
\text { eutrophication can increase } \\
\text { the susceptibility to } \\
\text { acidification }\end{array}$ & $\begin{array}{l}\text { Paerl and } \\
\text { Scott } \\
(2010) \text {, } \\
\text { Cai et al. } \\
\text { (2011), } \\
\text { Howarth } \\
\text { et al. } \\
\text { (2011) }\end{array}$ \\
\hline
\end{tabular}


Changes in growth and increased production from $\mathrm{N}$ enrichment are strong predictors of biodiversity decline (Clark et al. 2007). Increases in precipitation may increase ecosystem sensitivity to $\mathrm{N}$ deposition by enhancing primary limitation from $\mathrm{N}$, suggesting that future $\mathrm{N}$ deposition will have a larger effect over those parts of the US that are likely to experience greater precipitation (Rao et al. 2010). Additionally, impacts from $\mathrm{N}$ enrichment could be counterbalanced by elevated concentrations of $\mathrm{CO}_{2}$, which reduce $\mathrm{N}$ cycling in ecosystems and enhance soil water availability through reduced plant transpiration (Luo et al. 2004).

Despite being better-studied than most biomes, empirical evidence is scarce on the interactive effects of different drivers of diversity in grasslands. Generally, experimental $\mathrm{N}$ additions to grasslands result in substantial reductions in species diversity and greater losses in areas that are not also limited by other resources such as water (Bobbink 1998; Clark et al. 2007; Bobbink et al. 2010). In an experiment in annual Mediterranean grassland in California, where $\mathrm{N}$, temperature, precipitation, and $\mathrm{CO}_{2}$ were altered, the effects of these factors were additive, and the total effect led to a large loss of plant species, especially forbs (Zavaleta et al. 2003c). In an experiment in temperate perennial grassland in northern Minnesota where $\mathrm{CO}_{2}$ and $\mathrm{N}$ levels were altered, the reduction in diversity (mostly forbs) due to $\mathrm{N}$ addition was partly mitigated by elevated $\mathrm{CO}_{2}$ because elevated $\mathrm{CO}_{2}$ reduced soil $\mathrm{N}$ and increased soil moisture (Reich 2009). Thus, grassland diversity is likely to be sensitive to changes in $\mathrm{N}$ and climate, but the exact nature of these changes can vary from system to system.

Drylands

Plant growth is primarily constrained by water availability in arid systems (Noy-Meir 1973). However, when this constraint is lifted by increased precipitation, N limitation becomes increasingly important (Brooks 2003; Allen et al. 2009; Rao et al. 2010). In Joshua Tree National Park, $\mathrm{N}$ addition experiments increased non-native grass biomass and, where nonnative grass biomass was high, $\mathrm{N}$ decreased native forb species richness (Allen et al. 2009). In areas of the Mojave and Sonoran Deserts in southern California, a series of years with higher-than-average rainfall coupled with increased $\mathrm{N}$ deposition from the Los
Angeles Basin has promoted the growth of invasive Mediterranean grasses, creating a nearly continuous fuel layer in arid shrublands (Brooks and Minnich 2006; Rao et al. 2010). Fire frequency has increased, as has fire occurrence in areas previously unburned and unadapted to fire (Rao et al. 2010). Native shrubs may not be able to re-establish in these areas, as invasive grasses change the hydrology of the area, removing rainwater from the top layers of the soil thereby preventing its percolation into the root zone of young shrubs (Wood et al. 2006).

Nitrogen can exacerbate drought stress in drylands. In pinyon-juniper woodland of New Mexico, $\mathrm{N}$ fertilization decreased mycorrhizae and increased leaf production in pinyon pine, leading to increased drought-induced mortality (Allen et al. 2010).

\section{Wetlands}

Changes in $\mathrm{N}$ availability and climate may strongly impact species composition and biodiversity in wetlands (Greaver et al. 2011). Nitrogen is the limiting nutrient for plant growth in both freshwater and estuarine wetlands (LeBauer and Treseder 2008). Despite the high biodiversity in wetlands (USDANRCS 2009), the effects of $\mathrm{N}$ loading are studied in a limited number of plant species. Increased $\mathrm{N}$ availability or inputs may preferentially increase the growth of certain species, and since not all species respond equally, this may cause species dominance and composition to change. Sensitivity to $\mathrm{N}$ deposition in wetlands is generally thought to follow the pattern: bogs $>$ fens, marshes, swamps $>$ intertidal wetlands, representing the gradient from very low $\mathrm{N}$ conditions to very high $\mathrm{N}$ conditions. Because bogs receive nutrients exclusively from precipitation, they tend to be most sensitive wetland type to $\mathrm{N}$ deposition (Morris 1991). Other wetland types can be vulnerable to anthropogenic $\mathrm{N}$ enhancement from deposition as well as agricultural runoff via subsurface or surface waters. A recent study in a brackish marsh in Maryland found that $\mathrm{N}$-induced shifts in biodiversity from $\mathrm{C}_{3}$ to $\mathrm{C}_{4}$ species altered the community response to $\mathrm{CO}_{2}$ (Langley and Megonigal 2010). It has been shown that $\mathrm{N}$ loading can increase decomposition rates of organic matter and therefore, $\mathrm{C}$ loss, from salt marsh soils (Wigand et al. 2009). This could lead to degradation of the marsh structure and greater susceptibility to sea level increases. 
Freshwater systems

Human-driven biodiversity declines are expected to be far greater in freshwater than in terrestrial ecosystems (Sala et al. 2000). Aquatic ecosystems receive water and pollutants from the surrounding catchment, and lose water through landscape-scale withdrawals, and thus are particularly sensitive to anthropogenic change (Dudgeon et al. 2006). Freshwater ecosystems have been described as biological assets that are both disproportionately rich in diversity and disproportionally imperiled (Abramovitz 1996), and the combination of habitat loss, homogenization of flow regimes, and eutrophication has had drastic consequences on native freshwater organisms, including fishes, shellfish, and benthic invertebrates. About $37 \%$ of aquatic animal and $62 \%$ of aquatic plant species are considered at risk in the US (Heinz III 2008; Baron et al. 2002). Climate change has dramatic consequences for freshwaters because dissolved oxygen levels are sensitive to temperature, and flow changes can alter the concentrations and/or fluxes of nutrients. Many of the examples we identified in Table 1 for aquatic ecosystems involve synergistic interactions between $\mathrm{N}$ supply and climate change. For example, increases in temperature and changes in the timing and distribution of precipitation may exacerbate eutrophication and hypoxia in many ecosystems, particularly estuaries and coastal receiving waters.

Current levels of $\mathrm{N}$ in freshwaters and estuaries are a significant part of the problem by promoting noxious and harmful algal blooms, simplifying food webs, and creating favorable conditions for non-native species (Heinz III 2008). Warming, too, may promote local extirpation or migration of cold-obligate species and invasion of non-native species (Rahel and Olden 2008). Water temperature directly regulates oxygen concentrations, metabolic rates, and associated life processes. The thermal regime influences fitness and the distribution of species in both space (e.g., latitudinal and altitudinal gradients) and time (e.g., seasonal variation at a single location) (Baron et al. 2002). A survey of remote arctic and alpine lakes of North America and Greenland found that diversity of algal diatom assemblages has changed in these regions more significantly in the twentieth century than in the previous 350 years. Hobbs et al. (2010) noted that the greatest changes occurred in areas of most rapid warming (i.e., the Arctic) and areas with $\mathrm{N}$ deposition rates significantly elevated over natural background rates (i.e., alpine lakes), and predicted that diversity in remote lakes will continue to change, particularly in regions where climate change and $\mathrm{N}$ deposition interact. Whether from climate change, $\mathrm{N}$ availability, or both, the negative effect on biodiversity is expected to continue in the future.

Estuarine and near-coastal systems

Climate change can alter the responses of coastal waters to $\mathrm{N}$ pollution in the form of hypoxia, eutrophication, and harmful algal blooms (HABs) toxic to marine fish and wildlife and humans. Coastal ecosystems can become more or less sensitive to $\mathrm{N}$ pollution due to climate-driven changes in: (a) water residence time as it affects the time for phytoplankton blooms to occur; (b) ocean currents, as they affect the oxygen levels and nutrient content of water entering estuaries from the ocean; (c) stratification, which is driven by changes in temperature, freshwater discharge, winds and storms; and (d) ecological structure that is driven by temperature or a-c above. Examples of both enhanced and reduced sensitivity to $\mathrm{N}$ have been demonstrated for these cases. For instance, New York Harbor estuary has experienced greater occurrences of algal blooms and become much more eutrophic, as water residence times in summer have increased as a result of less winter snowpack in the Adirondack Mountains (Howarth 1998). The St. Lawrence Estuary and Gulf of St. Lawrence have become more sensitive to $\mathrm{N}$-induced hypoxia in recent years, as their bottom waters now come more from the deep Atlantic water, already low in oxygen, and less from the Labrador Current (Gilbert et al. 2005; Howarth et al. 2011). Due to greater stratification, productivity in the Dead Zone area in the Gulf of Mexico has become co-limited by $\mathrm{P}$, causing less $\mathrm{N}$ uptake, -cycling, and -loss in coastal environments and greater transport of $\mathrm{Nr}$ to deeper waters (Sylvan et al. 2006, Donner and Scavia 2007).

Several aspects of climate change that favor HABs include: longer periods of warm temperatures, increased intensity of vertical stratification, increased salinization, and increased intensity of storms and drought frequency and duration (Paerl and Scott 2010). Storms can increase nutrient loads to coastal zone while droughts increase residence times, retaining nutrients and exacerbating algal blooms. A number 
of estuaries have experienced hypoxia and HABs associated with altered nutrient loads during certain key seasonal periods (Howarth et al. 2000; Paerl 2006). Harmful algal blooms can dramatically alter ecosystem biodiversity, and influence recreation, fisheries and a host of other ecosystem services (Compton et al. 2011).

Oceans are also sensitive to atmospheric $\mathrm{CO}_{2}$ enrichment and climate change, with acidification and coral bleaching affecting coral reefs and other vulnerable ecosystems. Chronic stresses, such as nutrient loading, may make it more difficult for corals to adapt to climate impacts (Scavia et al. 2002). Eutrophication and warming, and associated hypoxia and anoxia, can greatly exacerbate ocean acidification because the respiration that drives oxygen consumption produces high levels of dissolved inorganic $\mathrm{C}$, including $\mathrm{CO}_{2}$ gas. The resulting acidification harms calcifying organisms such as mollusks and some crustaceans (Howarth et al. 2011).

\section{Evaluating risks from nitrogen enrichment and climate change on biodiversity}

In order to evaluate the risks from $\mathrm{N}$ enrichment and climate change on biodiversity, we must consider both the exposure and the sensitivity of ecosystems or regions to these two drivers. One tool for evaluating the susceptibility of ecosystems to detrimental effects of elevated $\mathrm{N}$ deposition is the critical load (CL). A CL is the deposition below which no harmful ecological effect occurs over the long term, according to present knowledge (UBA 2004). Empirical CLs (i.e., determined from experiments or observations along $\mathrm{N}$ deposition gradients) for $\mathrm{N}$ have been defined for specific areas, such as national parks (Baron 2006; Bowman et al. 2006; Rao et al. 2010). Empirical CLs have also been defined for ecoregions across the US for various responses including biodiversity or responses which could influence biodiversity (such as shifts in $\mathrm{N}$ availability, tissue $\mathrm{N}$ concentration, responses to secondary stressors, etc.) (Pardo et al. 2011a, b). Exceedance of the CL indicates regions at risk for detrimental effects from $\mathrm{N}$ deposition (Fig. 5). When the CL has been exceeded over many years or by a large amount, initial changes in biodiversity are more likely to have already occurred; the impact of additional $\mathrm{N}$ deposition may further alter species composition and biodiversity. When the deposition is near the CL, the risk of initial changes in biodiversity may be highest as was reported in the European Nitrogen Assessment (Dise et al. 2011). The extent, degree, and timing of detrimental impact varies by ecoregion and receptor (i.e., fungi, lichens, herbaceous species), but areas of exceedance occur in each ecoregion for which CLs were reported.

The greatest risks to biodiversity from $\mathrm{N}$ and climate change might be expected to occur where exceedance is high, climate change will be greatest, and responses are additive or amplifying. For example, in tundra ecosystems in Alaska where increasing temperature is likely to increase $\mathrm{N}$ availability further, impacts on biodiversity are likely to accelerate (Chapin et al. 1995; Chapin and Shaver 1996; Shaver et al. 2001). In addition to increases in temperature and precipitation volume, shifts in seasonal patterns in frequency and intensity of precipitation (including drought) may cause significant interactions with $\mathrm{N}$ enrichment and, ultimately, impact biodiversity. Given the complexity both in the types of changes in climate and their interactions with $\mathrm{N}$ enrichment in various ecosystems and for multiple species, dynamic modeling will be necessary to assess which ecosystems face the highest the risk of detrimental effects.

Summary of risk by regions to climate-N interactions

This section addresses the risk to biodiversity from climate- $\mathrm{N}$ interactions, synthesized by region. The climate information is drawn from the 2009 regional climate impacts section of the National Climate Assessment (NCA 2009). The information on N and climate- $\mathrm{N}$ interactions is from Table 1 , which presents an overview of the climate, $\mathrm{N}$ and climate- $\mathrm{N}$ impacts in major ecosystems of the US, with corresponding literature.

\section{Northeast}

Forests, lakes, wetlands and a number of estuaries dominate this region, along with a high density of urbanization. Reduced snowpack, longer and more frequent summer droughts, higher mean annual temperatures, higher average total precipitation, and more intense storms are expected for the forest and aquatic ecosystems that predominate the northeastern US 

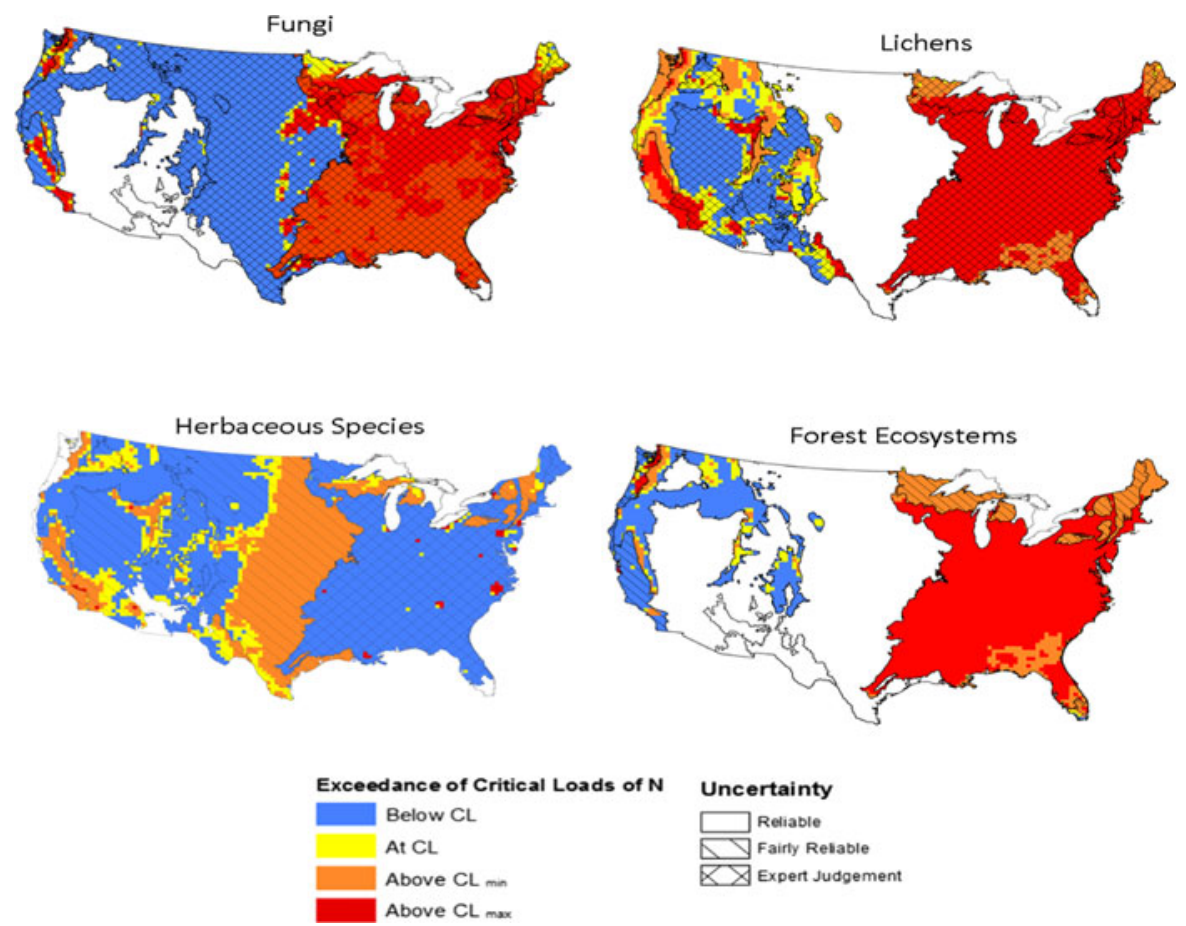

Fig. 5 Map of exceedance of critical load (CL) for nitrogen for mycorrhizal fungi, lichens, herbaceous species and shrubs, and forest ecosystems in the continental US. Exceedance was calculated by subtracting CLs from modeled nitrogen deposition. Exceedance is shown for several categories: (1) no exceedance (below CL), when deposition is lower than the CL range, (2) at CL, when deposition is within \pm 1 of the CL range, (3) above $\mathrm{CL}_{\min }$, when deposition is above the lower end of the

(NCA 2009). Fire (which is not common in the Northeast) and pest outbreaks are both expected to increase, impacting species composition. Nitrogen deposition is the highest for this US region due to a higher concentration of transportation and power generation activities. Much of the $\mathrm{N}$ deposited is in oxidized rather than reduced form, and remains above the critical load even though $\mathrm{N}$ deposition has been declining in recent decades.

Changes in terrestrial biodiversity for this ecoregion are likely slow due to the predominance of trees, but alterations in growth and survival due to $\mathrm{N}$ deposition have been reported (Thomas et al. 2010). Changes in understory species and in soil biodiversity due to $\mathrm{N}$ deposition may have already occurred in this area (Gilliam 2006; Hurd et al. 1998). Key interactions for the forests in this region include $\mathrm{N}$-driven reductions in freezing tolerance (Schaberg et al. 2002), which will have amplified impacts since the duration
CL range, but lower than the upper end of the range, (4) above $\mathrm{CL}_{\text {max }}$, when deposition is above the upper end of the CL range. White areas lack data for CL determination. The hatch marks indicate increasing level of uncertainty: no hatch marks for the most certain "reliable" category, single hatching for the "fairly reliable" category and cross-hatching for the "expert judgment" category (adapted from Pardo et al. 2011b)

and extent of the protective snow layer is expected to decrease under climate change. Finally, higher and more intense precipitation may exacerbate $\mathrm{N}$-induced nutrient imbalances in terrestrial plants, as more nutrient cations are leached from the rooting zone. Changes in aquatic biodiversity for this ecoregion also have been reported (e.g., Howarth et al. 2011), and will likely continue. Eutrophication of lakes and estuaries will likely be amplified under climate change, with a greater extent and duration of hypoxic events in impacted coastal systems.

\section{Southeast}

The Southeastern US is dominated inland by broadleaf and mixed forests that are some of the most diverse in North America, as well as by large coastal wetlands and marshes. Climate in this region is expected to continue to warm especially in the winter, and 
continue to get drier especially in the spring and summer months, with more intense storms overall (Karl et al. 2009). Fire, drought, and insect outbreaks are expected to be more prevalent with climate change (NCA 2009). Despite the fact that N deposition levels are lower than in the Northeast, many regions of the Southeast experience $\mathrm{N}$ deposition at levels that may affect biodiversity (Pardo et al. 2011a, b).

Nitrogen deposition is more balanced between oxidized and reduced forms compared with the Northeast or Midwest because of the combined influences of industry and agriculture in the Southeast, though the majority still falls as oxidized N. Key interactions for terrestrial ecosystems in this region include a potential increase in susceptibility to drought and pests. Increased aboveground growth in N-limited systems may also make them more prone to fire. The Southeast is not expected to dry to levels more common in co-limited ( $\mathrm{N}$ and water) environments in the western Great Plains, making $\mathrm{N}$ limitation likely to continue, and thus $\mathrm{N}$ sensitivity to remain.

Key interactions for aquatic ecosystems include a potential decrease in long-term average $\mathrm{N}$ loads from decreased precipitation, punctuated with large synoptic flushes of $\mathrm{N}$ from increased storm events and intensities. It is unknown how the impacts from these contrasting factors will play out for aquatic biodiversity. Climate change is expected to result in sea level rise and increased flooding of coastal areas in this region, and the interaction with $\mathrm{N}$ may exacerbate eutrophication in these areas. Recent work has also shown that eutrophication may exacerbate coastal acidification in these areas (Cai et al. 2011), illustrating a synergistic interaction between climate and $\mathrm{N}$ loads.

\section{Midwest and Great Plains}

Rangeland, farmland, and grassland dominate much of this region. Because of the favorable conditions for agriculture, many natural systems have been converted for human use, and only fragmented and dispersed natural habitats remain (Leach and Givnish 1996; Samson and Knopf 1994). The remaining natural ecosystems that are already under stress are anticipated to become warmer and wetter (NCA 2009), which could intensify N limitation and sensitivity to $\mathrm{N}$. Deposition of $\mathrm{N}$ in this area is moderate, declining from east to west, and dominated by reduced forms of $\mathrm{N}$, ammonia $\left(\mathrm{NH}_{3}\right)$ and ammonium $\left(\mathrm{NH}_{4}{ }^{+}\right)$, due to the abundance of agriculture. Key interactions for these systems include decreased co-limitation by water and $\mathrm{N}$, and increased preponderance of limitation by $\mathrm{N}$ (Clark et al. 2007). This could increase stresses on plant biodiversity from increased plant growth and competition.

Important wetlands and lakes in this region are expected to undergo synergistic interactions between $\mathrm{N}$ and climate change, where warmer, wetter conditions could increase nutrient loading to aquatic ecosystems, leading to higher levels of eutrophication and low oxygen conditions. Many wetlands in this region provide important habitats for migrating waterfowl. Forests and alpine systems dominate the western portions of this region in the mountainous areas of Wyoming and Montana. Earlier snowmelt associated with elevated temperatures has been shown to harm some species of wildflowers through increased frost damage (Inouye 2008). Although current $\mathrm{N}$ deposition to these regions is generally low, frost damage might be expected to be enhanced with increased $\mathrm{N}$ deposition due to increased growth aboveground exposing more tissue to cold stress.

\section{Northwest}

Forests generally dominate the Northwestern region with agriculture in many river valleys, and steppe in drylands. Rivers and coastal ecosystems play an important role in the local economy. Elevated temperatures in the Northwest will lead to greater winter precipitation as rain, decreased snowpack, reduced stream flows in the summer, and reduced water availability during peak plant growth periods (Karl et al. 2009). These hydrologic changes are expected to alter aquatic communities and drive declines in fish, especially cold-water species such as salmon. Stream networks are likely to constrict with lower summer water conditions, threatening the integrity of aquatic ecosystems, although increased total precipitation may offset some of these changes.

Inputs of $\mathrm{N}$ are lower in the Northwest on average than the Eastern US, though some aquatic and terrestrial ecosystems in the region are stressed in areas dominated by agriculture and industry. For example, increasing $\mathrm{N}$ deposition in areas around large cities is already affecting lichen community composition in the Northwest (Geiser et al. 2010). Key 
interactions in this region include the increased frost damage from earlier snowmelt combined with $\mathrm{N}$ deposition (already observed in the Rockies as described above), greater total precipitation and storm intensities delivering larger amounts of $\mathrm{N}$ to aquatic systems, possible shifts in forest tree composition from longer growing seasons and $\mathrm{N}$ deposition as observed in the east (Thomas et al. 2010), and increased pest damage from populations feeding on more $\mathrm{N}$-rich tissue in a warmer environment. Changes in climate and in $\mathrm{N}$ loading may impact coastal fisheries, although the dynamics of ocean currents play a large role in the coastal ecosystems, and current research indicates that the extent and duration of coastal hypoxic zones are influenced by ocean circulation (Chan et al. 2008). Also, in some Pacific Northwest coastal systems, it has been observed that watershed derived nutrients can acidify coastal waters at a faster rate than atmospheric $\mathrm{CO}_{2}$ alone (Kelly et al. 2011).

\section{Southwest}

Climate change in the forest and desert ecosystems in the Southwestern US is expected to lead to increased temperatures, decreased precipitation, and increased droughts and extreme events (Karl et al. 2009). This will likely make them more susceptible to fire and pests. Nitrogen deposition, although not as extensive by comparison with the east, is high nearer to urban and agricultural areas (Fenn et al. 2003), and will likely contribute to climate-driven increases in fire frequency (through increased grass growth in shrub interspaces) and pest stresses (through increased tissue $\mathrm{N})$. An additional key interaction is air quality, which is already poor in this region. Climate change and increased $\mathrm{N}$ will continue to result in high ozone levels in the mountains near large cities in California and other Southwestern cities.

\section{Alaska}

Alaska is expected to have large changes in climate, but the changes in $\mathrm{N}$ loading are not expected to be significant in the future, except possibly in concentrated areas around cities or ports. The potential impacts related to climate- $\mathrm{N}$ interactions are likely to be from alterations of the internal $\mathrm{N}$ cycle, for example, increasing decomposition rates, increasing $\mathrm{N}$ availability and shifting competitive balances. In addition, because critical loads are so low for some of these low- biomass systems, small increases in $\mathrm{N}$ deposition could result in significant changes (Pardo et al. 2011a, b).

\section{Coasts}

Aquatic ecosystems, particularly coastal systems, are at high risk for impacts on biodiversity driven by interacting climate change and $\mathrm{N}$ inputs. Warmer conditions and higher nutrients will generally lead to increases in aquatic production, eutrophication and decreased dissolved oxygen levels. Eutrophication of $\mathrm{N}$-limited systems, in turn, will be exacerbated in the warmer conditions with lower water levels. Wetlands and lakes also are at risk for altering biodiversity due to contracting water networks and increased eutrophication. Eelgrass decline has also been associated with high nutrients and eutrophication, and will alter aquatic habitat space and the distribution and abundance of the species that use those areas (Latimer and Rego 2010).

\section{Modeling}

Various approaches have been used to estimate changes in biodiversity due to climate change and they typically couple indirect drivers of biodiversity (e.g., population growth, fossil fuel use), direct drivers (e.g., climate, pollution, land-use change), and biodiversity models (e.g., dynamic vegetation models, niche models, and dose-response relationships) (Pereira et al. 2010). Species distribution models (SDMs), that relate field observations to environmental variables, have been widely used to forecast the impacts on biodiversity from a variety of stressors, including climate change. These niche-based models predict the potential distribution of species based on the species' bioclimatic envelope, sometimes integrated with limiting factors of dispersal, disturbance, and resource availability (Guisan and Thuiller 2005). Process-based models, on the other hand, incorporate the underlying mechanisms that influence species response, such as $\mathrm{N}$ and $\mathrm{C}$ cycling in soils. Some of these models can also simulate changes in ecosystems over time due to changes in temperature and precipitation, making them useful for studying possible responses associated with climate change (Dise et al. 2011). 
Linking process-based models to niche-based models may be particularly important for improving forecasts of plant distribution (Keenan et al. 2011). The ForSAFE-VEG model links the dynamic soil biogeochemistry model ForSAFE with the plant response model VEG to forecast changes in plant communities from impact of $\mathrm{N}$ deposition and climate change, and has been applied in the EU in Sweden and Switzerland (Sverdrup et al. 2007; Belyazid et al. 2011) and in the US Rocky Mountains (Sverdrup et al. 2012). For a generalized plant community in the US Rocky Mountains, the model suggests that $\mathrm{N}$ has exacerbated reductions in biodiversity expected from climate change alone (Fig. 6; Sverdrup et al. 2012). In Britain, the Model of Acidification of Groundwater in Catchments (MAGIC) model (Cosby et al. 2001), which focuses on acid-base relationships but includes an $\mathrm{N}$ module, has been linked with a plant niche model to simulate plant community changes with $\mathrm{N}$ and climate change (Rowe et al. 2005). Another biogeochemical model, the PnET-BGC (has been used in the US to simulate soil and vegetation dynamics under various scenarios of $\mathrm{N}$ and sulfur deposition and climate change (Wu and Driscoll 2010). In addition, the DayCent-Chem (daily version of the CENTURY model) model has been used to simulate daily surface
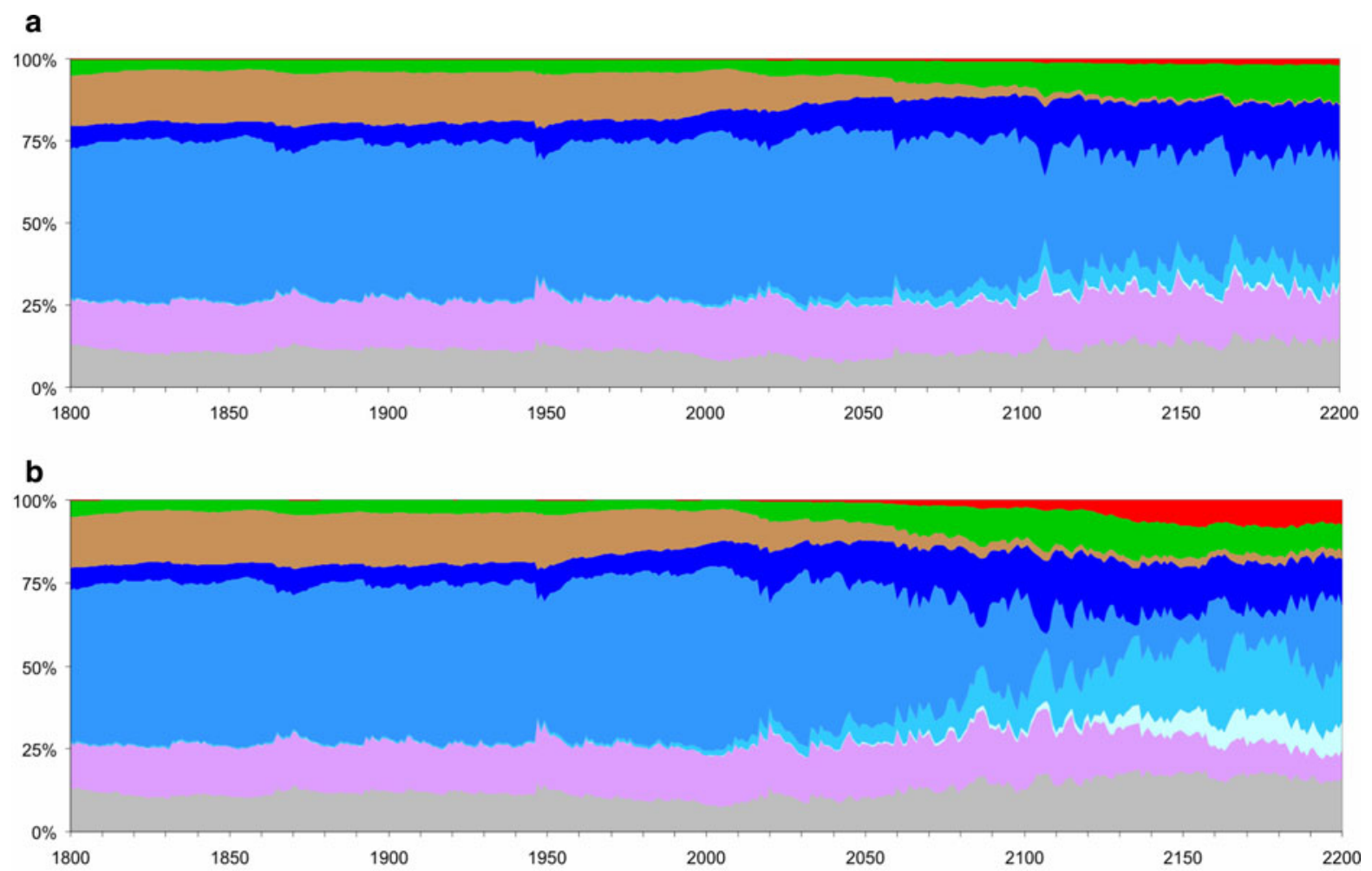

\section{$\underline{\text { Trees }}$ \\ Mixed trees \\ Shrubs \\ Mixed shrubs \\ Forbs \\ Mixed forbs}

Fig. 6 ForSAFE-VEG model simulations for plant life form coverage based on the IPCC climate change scenario A2 for the Rocky Mountain region and a estimated background $\mathrm{S}$ and $\mathrm{N}$ deposition and b elevated future atmospheric $\mathrm{N}$ deposition (modified from Sverdrup et al. 2012) 
water and ecosystem responses to $\mathrm{N}$ and sulfur and climate change (Hartman et al. 2007).

Models are always limited by available data on ecosystem response and by the scale of that data. But ForSAFE-VEG (a model that simulates soil chemistry, $\mathrm{C}$ and $\mathrm{N}$ cycling, tree growth, geochemistry, and ground vegetation response) and other models show promise as tools to forecast $\mathrm{N}$ and climate change interactions, and are likely to be used more widely as the ecosystem response data needed to calibrate the models become available.

\section{Management and policy options for reducing impacts on biodiversity}

There are several ways that management and policy may alleviate the interactive effects of climate change and excess $\mathrm{N}$ on biodiversity. As a foundation, there must be sufficient understanding of how much and where (1) $\mathrm{N}$ is being deposited, and (2) climate is changing. For the former, national monitoring networks (e.g., National Atmospheric Deposition Program-NADP; Clean Air Status and Trends Network-CASTNET) and dynamic atmospheric models (e.g., Community Multi-scale Air Quality-CMAQ), have been developed to generate national estimates of $\mathrm{N}$ deposition (Weathers and Lynch 2011These tools are critical in developing action plans to manage impacts on biodiversity. However, there are still significant limitations including sparse coverage nationally especially for remote and mountainous areas, lack of monitoring for some $\mathrm{N}$ species altogether (e.g., organic $\mathrm{N}$ ), and poor sampling or infrequent sampling for some processes (e.g., dry and fog deposition). Other limitations for the models include incomplete process modeling (e.g., cloud deposition, bidirectional $\mathrm{N}$ flows) and incomplete calibration (Weathers et al. 2006; Pardo et al. 2011b, Peel et al., this issue). For the latter, the US Global Change Research Program has developed comprehensive reports (in 2000, 2009, and scheduled for 2013) that synthesize the state of knowledge from multiple Agency and non-Agency national and international efforts on how and where climate is changing and expected to change in the future for the US (Karl et al. 2009).

Appropriate actions for managing the interactive impacts on biodiversity from $\mathrm{N}$ and climate change depend largely on the dominant mechanism driving biodiversity change. First and foremost is reducing the emissions of $\mathrm{N}$ to the environment that are subsequently transported to and deposited on potentially sensitive systems. Several approaches have been proposed (e.g., US EPA 2011) that depend largely on the source of emissions, whether agricultural- or fossil fuel combustion-based. At the other end of the management spectrum are interventions in impacted areas. Reduction of $\mathrm{N}$ inputs and the restoration of $\mathrm{N}$ and other soil resource conditions will not necessarily guarantee that the original species will return. Species may no longer be present in the degraded habitat or able to disperse there over a fragmented landscape. Seeds of many target grassland species of high biodiversity value are known not to remain viable for more than a few years to a decade in the seed bank (Thompson et al. 1998), suggesting that historical $\mathrm{N}$ deposition over the past 50 years could have dramatically altered seed availability to systems thereby necessitating seed addition. This replanting is commonly termed "assisted migration" in the climate literature (IPCC 2007), and may be required for systems where the dominant driver of biodiversity change is climate-induced shifts in range.

In addition to reducing $\mathrm{N}$ inputs into ecosystems, several approaches have been proposed to reduce $\mathrm{N}$ stores and cycling, including increasing $\mathrm{N}$ export through harvesting, turf removal, or fire, increasing $\mathrm{N}$ leaching through flushing with aqueous solutions, and decreasing $\mathrm{N}$ availability through the addition of $\mathrm{C}$ (Bakker and Berendse 1999; Blumenthal et al. 2003; Jordan et al. 2003). Some of these approaches may only redistribute existing $\mathrm{Nr}$ rather than removing it such as through denitrification (Galloway et al. 2003). For systems in which $\mathrm{N}$-induced soil acidification dominates, addition of soil amendments (e.g., lime, magnesium) may be used to increase soil $\mathrm{pH}$, inhibit $\mathrm{NH}_{4}{ }^{+}$accumulation, and restore nutrient balances (Bakker and Berendse 1999; Dise et al. 2011). However, aggressive strategies such as biomass removal and soil amendments have limited usefulness because such treatments require periodic application to be effective and are costly and labor intensive, and in some areas may be prohibited because of land protection mandates (e.g., national parks or wilderness) (Fenn et al. 2010).

Because of the significant problems associated with most forms of aggressive intervention management, 
reduction of $\mathrm{N}$ deposition to ecosystems is the best strategy for long-term success in managing impacts from climate and $\mathrm{N}$ deposition on biodiversity (Fenn et al. 2010, 2011; Bobbink et al. 2010). A review of available $\mathrm{N}$ mitigation strategies for California concluded that the ideal management option for reducing effects of $\mathrm{N}$ excess is to reduce $\mathrm{N}$ deposition by improving air quality (Fenn et al. 2010). Reducing N deposition can occur through many policy approaches, including the establishment of critical loads, and through allowing tradable permits for pollution which are slowly removed from the market, thereby reducing total pollution. In many countries including the US, emissions and deposition of nitrogen oxides $\left(\mathrm{NO}_{\mathrm{x}}\right)$ have decreased dramatically in the past 20 years as a result of regulatory policies (Fenn et al. 2010). However, similar controls for emissions of $\mathrm{NH}_{3}$ are less prevalent and the proportion of $\mathrm{N}$ deposition occurring in reduced forms $\left(\mathrm{NH}_{\mathrm{x}}\right)$ is increasing in many areas above levels known to have ecological effects on more sensitive taxa (Clarisse et al. 2009; Fenn et al. 2010). This highlights the importance of selecting the appropriate receptor to use when implementing critical loads. The impacts to plant and lichen biodiversity in terrestrial ecosystems occur at lower air pollution levels than impacts on human health, and effects to non-vascular biodiversity occur at lower air pollution levels than effects to vascular biodiversity (Bobbink et al. 2010; Pardo et al. 2011a, b). Thus when air pollution standards are determined primarily or solely by impacts to human health, in many cases sensitive ecosystems and biodiversity will not be effectively protected. Furthermore, the $\mathrm{N}$-induced loss of ecosystem services has serious consequences for human health and well-being (Compton et al. 2011).

\section{Summary and key research needs}

Biodiversity is decreasing worldwide and in the US, with serious consequences for ecosystem services including water quality regulation, production of food and fiber, and disease resistance. Although biodiversity losses have been largely driven by land use changes to date, climate change and increases in $\mathrm{Nr}$ are recognized as increasingly important drivers of biodiversity. The interactive effects of climate change and $\mathrm{N}$ are just beginning to be understood, and effects may vary across ecosystems. In general, $\mathrm{N}$ and climate change separately reduce biodiversity in sensitive systems, and together have the potential to cause even greater losses. In summary:

- Nitrogen is a strong driver of biodiversity loss in many types of ecosystems. The effects of climate change are less certain, although there is evidence that changes in precipitation and temperature, increases in drought, floods, and other disturbances can result in simplified, less diverse systems.

- Many areas of the US are now receiving $\mathrm{N}$ deposition in excess of critical loads for ecosystem health, including for biodiversity. Some of these areas are also undergoing rapid climate change and are at heightened risk for biodiversity losses from combined $\mathrm{N}$ and climate change effects.

- Focused empirical studies are needed to obtain additional response data to changes in $\mathrm{N}$, temperature, precipitation, and $\mathrm{CO}_{2}$, and the interactions of these stressors in those ecosystems most vulnerable to $\mathrm{N}$ and climate change. This response data will improve modeled estimates of future conditions affected by $\mathrm{N}$ and climate change interactions.

- Reducing N deposition is likely to be an effective strategy for mitigating climate change impacts on biodiversity.

Acknowledgments Many thanks to Eric Davidson and Emma Suddick for their assistance and help with planning and preparing this manuscript. Thanks to Nancy Dise, Edith Allen, and Rich Pouyat for providing thoughtful and helpful reviews of an older draft. This work resulted from a workshop supported by NSF Research Coordination Network awards DEB-0443439 and DEB-1049744 and by the David and Lucille Packard Foundation.

Open Access This article is distributed under the terms of the Creative Commons Attribution License which permits any use, distribution, and reproduction in any medium, provided the original author(s) and the source are credited.

\section{References}

Abramovitz J (1996) Imperiled waters, impoverished future: the decline of freshwater ecosystems. Worldwatch Paper \#128. Worldwatch Institute, New York

Ackerly DD, Bazzaz FA (1995) Plant-growth and reproduction along $\mathrm{CO}_{2}$ gradients-nonlinear responses and implications for community change. Glob Change Biol 1(3): 199-207 
Adair EC, Reich PB, Hobbie SE, Knops JMH (2009) Interactive effects of time, $\mathrm{CO}(2), \mathrm{N}$, and diversity on total belowground carbon allocation and ecosystem carbon storage in a grassland community. Ecosystems 12(6):1037-1052

Aerts R, Chapin FS (2000) The mineral nutrition of wild plants revisited: a re-evaluation of processes and patterns. Adv Ecol Res 30:1-67

Aldous AR (2002) Nitrogen retention by Sphagnum mosses: responses to atmospheric nitrogen deposition and drought. Can J Bot 80:721-731

Alkemade R, van Oorschot M, Miles L, Nellemann C, Bakkenes $\mathrm{M}$, ten Brink B (2009) GLOBIO3: a framework to investigate options for reducing global terrestrial biodiversity loss. Ecosystems 12(3):374-390

Allen EB, Rao LE, Steers RJ, Bytnerowicz A, Fenn ME (2009) Impacts of atmospheric nitrogen deposition on vegetation and soils in Joshua Tree National Park. In: Webb RH, Fenstermaker LF, Heaton JS, Hughson DL, McDonald EV, Miller DM (eds) The Mojave Desert: ecosystem processes and sustainability. University of Nevada Press, Las Vegas, pp 78-100

Allen MF, Allen EB, Lansing JL, Pregitzer KS, Hendrick RL, Ruess RW, Collins SL (2010) Responses to chronic N fertilization of ectomycorrhizal pinon but not arbuscular mycorrhizal juniper in a pinon-juniper woodland. J Arid Environ 74:1170-1176

Arens SJT, Sullivan PF, Welker JM (2008) Nonlinear responses to nitrogen and strong interactions with nitrogen and phosphorus additions drastically alter the structure and function of a high arctic ecosystem. J Geophys Res Biogeosci 113:G03509

Bakker JP, Berendse F (1999) Constraints in the restoration of ecological diversity in grassland and heathland communities. Trends Ecol Evol 14(2):63-68

Bale JS, Masters GJ, Hodkinson ID, Awmack C, Bezemer TM, Brown VK, Butterfield J, Buse A, Coulson JC, Farrar J, Good JEG, Harrington R, Hartley S, Jones TH, Lindroth RL, Press MC, Symrnioudis I, Watt AD, Whittaker JB (2002) Herbivory in global climate change research: direct effects of rising temperature on insect herbivores. Glob Change Biol 8(1):1-16

Balvanera P, Pfisterer AB, Buchmann N, He JS, Nakashizuka T, Raffaelli D, Schmid B (2006) Quantifying the evidence for biodiversity effects on ecosystem functioning and services. Ecol Lett 9(10):1146-1156

Baron JS (2006) Hindcasting nitrogen deposition to determine an ecological critical load. Ecol Appl 16(4)

Baron JS, Poff NL, Angermeier PL, Dahm CN, Gleick PH, Hairston NG, Jackson RB, Johnston CA, Richter BD, Steinman AD (2002) Meeting ecological and societal needs for freshwater. Ecol Appl 12(5):1247-1260

Baron JS, Schmidt TM, Hartman MD (2009) Climate-induced changes in high elevation stream nitrate dynamics. Glob Change Biol 15(7):1777-1789

Bedford BL, Walbridge MR, Aldous A (1999) Patterns in nutrient availability and plant diversity of temperate North American wetlands. Ecology 80:2151-2169

Belyazid S, Kurz D, Braun S, Sverdrup H, Rihm B, Hettelingh JP (2011) A dynamic modelling approach for estimating critical loads of nitrogen based on pliant community changes under a changing climate. Environ Pollut 159(3): 789-801

Bentz BJ, Regniere J, Fettig CJ, Hansen EM, Hayes JL, Hicke JA, Kelsey RG, Negron JF, Seybold SJ (2010) Climate change and bark beetles of the Western United States and Canada: direct and indirect effects. Bioscience 60(8): 602-613

Blumenthal DM, Jordan NR, Russelle MP (2003) Soil carbon addition controls weeds and facilitates prairie restoration. Ecol Appl 13(3):605-615

Bobbink R (1998) Impacts of tropospheric ozone and airborne nitrogenous pollutants on natural and seminatural ecosystems: a commentary. New Phytol 139(1):161-168

Bobbink R, Hicks K, Galloway J, Spranger T, Alkemade R, Ashmore M, Bustamante M, Cinderby S, Davidson E, Dentener F, Emmett B, Erisman JW, Fenn M, Gilliam F, Nordin A, Pardo L, De Vries W (2010) Global assessment of nitrogen deposition effects on terrestrial plant diversity: a synthesis. Ecol Appl 20(1):30-59

Bowman WD, Steltzer H (1998) Positive feedbacks to anthropogenic nitrogen deposition in Rocky mountain alpine tundra. AMBIO 27:514-517

Bowman WD, Gartner JR, Holland K, Wiedermann M (2006) Nitrogen critical loads for alpine vegetation and terrestrial ecosystem response: are we there yet? Ecol Appl 16:1183-1193

Brooks ML (2003) Effects of increased soil nitrogen on the dominance of alien annual plants in the Mojave Desert. J Appl Ecol 40(2):344-353

Brooks ML, Minnich RA (2006) Southeastern deserts bioregion. In: Sugihara NG, Wagtendonk JWV, Shaffer KE, FitesKaufman J, Thode AE (eds) Fire in California's ecosystems. University of California Press, Berkeley, pp 391-414

Brooks ML, D'Antonio CM, Richardson DM, Grace JB, Keeley JE, DiTomaso JM, Hobbs RJ, Pellant M, Pyke D (2004) Effects of invasive alien plants on fire regimes. Bioscience 54(7):677-688

Butchart SHM, Walpole M, Collen B, van Strien A, Scharlemann JPW, Almond REA, Baillie JEM, Bomhard B, Brown C, Bruno J, Carpenter KE, Carr GM, Chanson J, Chenery AM, Csirke J, Davidson NC, Dentener F, Foster M, Galli A, Galloway JN, Genovesi P, Gregory RD, Hockings M, Kapos V, Lamarque JF, Leverington F, Loh J, McGeoch MA, McRae L, Minasyan A, Morcillo MH, Oldfield TEE, Pauly D, Quader S, Revenga C, Sauer JR, Skolnik B, Spear D, Stanwell-Smith D, Stuart SN, Symes A, Tierney M, Tyrrell TD, Vie JC, Watson R (2010) Global biodiversity: indicators of recent declines. Science 328 (5982):1164-1168

Butler SM, Melillo JM, Johnson JE, Mohan J, Steudler PA, Lux H, Burrows E, Smith RM, Vario CL, Scott L, Hill TD, Aponte NA, Bowles F (2011) Soil warming alters nitrogen cycling in a New England forest: implications for ecosystem function and structure. Oecologia. doi:10.1007/ s00442-00011-02133-00447

Cai WJ, Hu XP, Huang WJ, Murrell MC, Lehrter JC, Lohrenz SE, Chou WC, Zhai WD, Hollibaugh JT, Wang YC, Zhao PS, Guo XH, Gundersen K, Dai MH, Gong GC (2011) Acidification of subsurface coastal waters enhanced by eutrophication. Nat Geosci 4(11):766-770 
CBD (Convention on Biological Diversity) (1992) Convention on Biological Diversity, Rio de Janeiro, Argentina. http:// www.biodiv.org/convention

Chan F, Barth JA, Lubchenco J, Kirincich A, Weeks H, Peterson WT, Menge BA (2008) Emergence of anoxia in the California current large marine ecosystem. Science 319(5865)

Chapin FS, Shaver GR (1996) Physiological and growth responses of arctic plants to a field experiment simulating climatic change. Ecology 77(3):822-840

Chapin FS, Shaver GR, Giblin AE, Nadelhoffer KJ, Laundre JA (1995) Responses of arctic tundra to experimental and observed changes in climate. Ecology 76(3):694-711

Chapin FS, Zavaleta ES, Eviner VT, Naylor RL, Vitousek PM, Reynolds HL, Hooper DU, Lavorel S, Sala OE, Hobbie SE, Mack MC, Diaz S (2000) Consequences of changing biodiversity. Nature 405(6783):234-242

Chase JM, Leibold MA (2002) Spatial scale dictates the productivity-biodiversity relationship. Nature 416(6879): 427-430

Clarisse L, Clerbaux C, Dentener F, Hurtmans D, Coheur PF (2009) Global ammonia distribution derived from infrared satellite observations. Nat Geosci 2(7):479-483

Clark CM, Tilman D (2008) Loss of plant species after chronic low-level nitrogen deposition to prairie grasslands. Nature 451(7179):712-715

Clark CM, Cleland EE, Collins SL, Fargione JE, Gough L, Gross KL, Pennings SC, Suding KN, Grace JB (2007) Environmental and plant community determinants of species loss following nitrogen enrichment. Ecol Lett 10(7): 596-607

Cleland EE, Chiariello NR, Loarie SR, Mooney HA, Field CB (2006) Diverse responses of phenology to global changes in a grassland ecosystem. Proc Natl Acad Sci 103: 13740-13744

Cleland EE, Chuine I, Menzel A, Mooney HA, Schwartz MD (2007) Shifting plant phenology in response to global change. Trends Ecol Evol 22(7):357-365

Collins SL, Knapp AK, Briggs JM, Blair JM, Steinauer EM (1998) Modulation of diversity by grazing and mowing in native tallgrass prairie. Science 280(5364):745-747

Collins SL, Koerner SE, Plaut JA, Okie JG, Brese D, Calabrese LB, Carvajal A, Evansen RJ, Nonaka E (2012) Stability of tallgrass prairie during a 19-year increase in growing season precipitation. Funct Ecol. doi:10.1111/j.1365-2435. 2012.01995

Compton JE, Harrison JA, Dennis RL, Greaver TL, Hill BH, Jordan SJ, Walker H, Campbell HV (2011) Ecosystem services altered by human changes in the nitrogen cycle: a new perspective for US decision making. Ecol Lett 14(8):804-815

Cornelissen JHC, Callaghan TV, Alatalo JM, Michelsen A, Graglia E, Hartley AE, Hik DS, Hobbie SE, Press MC, Robinson CH, Henry GHR, Shaver GR, Phoenix GK, Gwynn Jones D, Jonasson S, Chapin FS, Molau U, Neill C, Lee JA, Melillo JM, Sveinbjörnsson B, Aerts R (2001) Global change and arctic ecosystems: is lichen decline a function of increases in vascular plant biomass? J Ecol 89(6):984-994

Cosby BJ, Ferrier RC, Jenkins A, Wright RF (2001) Modelling the effects of acid deposition: refinements, adjustments and inclusion of nitrogen dynamics in the MAGIC model. Hydrol Earth Syst Sci 5(3):499-517

Crain CM (2007) Shifting nutrient limitation and eutrophication effects in marsh vegetation across estuarine salinity gradients. Estuaries Coasts 30(1):26-34

Darby FA, Turner RE (2008a) Below- and aboveground Spartina alterniflora production in a Louisiana salt marsh. Estuaries Coasts 31:223-231

Darby FA, Turner RE (2008b) Below- and aboveground biomass of Spartina alterniflora: response to Nutrient Addition in a Louisiana Salt Marsh. Estuaries Coasts 31:326-334

DeHayes DH, Schaberg PG, Hawley GJ, Strimbeck GR (1999) Acid rain impacts on calcium nutrition and forest healthalteration of membrane-associated calcium leads to membrane destabilization and foliar injury in red spruce. Bioscience 49(10):789-800

Dise NB, Matzner E, Armbruster M, MacDonald J (2001) Aluminum output fluxes from forest ecosystems in Europe: a regional assessment. J Environ Qual 30:1747-1756

Dise N, Ashmore M, Belyazid S, Bleeker A, Bobbink R, de Vries W, Erisman JW, Spranger T, Stevens CJ, van den Berg L (2011) Nitrogen as a threat to European terrestrial biodiversity. In: Sutton MA (ed) The European nitrogen assessment. Cambridge University Press, Cambridge

Donner SD, Scavia D (2007) How climate controls the flux of nitrogen by the Mississippi River and the development of hypoxia in the Gulf of Mexico. Limnol Oceanogr 52(2):856-861

Dudgeon D, Arthington AH, Gessner MO, Kawabata ZI, Knowler DJ, Leveque C, Naiman RJ, Prieur-Richard AH, Soto D, Stiassny MLJ, Sullivan CA (2006) Freshwater biodiversity: importance, threats, status and conservation challenges. Biol Rev 81(2):163-182

Dukes JS, Chiariello NR, Loarie SR, Field CB (2011) Strong response of an invasive plant species (Centaurea solstitialis L.) to global environmental changes. Ecol Appl 20071:1887-1894

Dupré C, Stevens CJ, Ranke T, Bleeker A, Peppler-Lisbach C, Gowing DJG, Dise NB, Dorland E, Bobbink R, Diekmann $M$ (2010) Changes in species richness and composition in European acidic grasslands over the past 70 years: the contribution of cumulative atmospheric nitrogen deposition. Glob Change Biol 16(1):344-357

Elser JJ, Bracken MES, Cleland EE, Gruner DS, Harpole WS, Hillebrand H, Ngai JT, Seabloom EW, Shurin JB, Smith JE (2007) Global analysis of nitrogen and phosphorus limitation of primary producers in freshwater, marine and terrestrial ecosystems. Ecol Lett 10(12):1135-1142

Elser JJ, Andersen T, Baron JS, Bergstrom AK, Jansson M, Kyle M, Nydick KR, Steger L, Hessen DO (2009) Shifts in Lake $\mathrm{N}: \mathrm{P}$ stoichiometry and nutrient limitation driven by atmospheric nitrogen deposition. Science 326(5954):835-837

Fenn ME, Haeuber R, Tonnesen GS, Baron JS, GrossmanClarke S, Hope D, Jaffe DA, Copeland S, Geiser L, Rueth HM, Sickman JO (2003) Nitrogen emissions, deposition, and monitoring in the western United States. Bioscience 53:391-403

Fenn ME, Allen EB, Weiss SB, Jovan S, Geiser LH, Tonnesen GS, Johnson RF, Rao LE, Gimeno BS, Yuan F, Meixner T, Bytnerowicz A (2010) Nitrogen critical loads and 
management alternatives for $\mathrm{N}$-impacted ecosystems in California. J Environ Manage 91(12):2404-2423

Fenn ME, Lambert KF, Blett TF, Burns DA, Pardo LH, Lovett GM, Haeuber RA, Evers DC, Driscoll CT, Jeffries DS (2011) Setting limits: using air pollution thresholds to protect and restore US Ecosystems, Issues in Ecology, Report No. 14. Ecological Society of America, Washington, DC

Foster BL, Tilman D (2003) Seed limitation and the regulation of community structure in oak savanna grassland. J Ecol 91(6):999-1007

Galloway JN, Aber JD, Erisman JW, Seitzinger SP, Howarth RW, Cowling EB, Cosby BJ (2003) The nitrogen cascade. Bioscience 53(4):341

Galloway JN, Dentener FJ, Capone DG, Boyer EW, Howarth RW, Seitzinger SP, Asner GP, Cleveland C, Green P, Holland E, Karl DM, Michaels AF, Porter JH, Townsend A, Vorosmarty C (2004) Nitrogen cycles: past, present and future. Biogeochemistry 70:153-226

Gaston KJ (2000) Global patterns in biodiversity. Nature 405(6783):220-227

Geiser LH, Nadelhoffer K (2011) Chapter 6: Taiga. In: Pardo LH, Robin-Abbott MJ, Driscoll CT (eds) Assessment of nitrogen deposition effects and empirical critical loads of Nitrogen for ecoregions of the United States. General Technical Report NRS-80. US Department of Agriculture, Forest Service, Northern Research Station, Newtown Square, PA, pp 49-60

Geiser LH, Jovan SE, Glavich DA, Porter MK (2010) Lichenbased critical loads for atmospheric nitrogen deposition in Western Oregon and Washington Forests, USA. Environ Pollut 158(7):2412-2421

Gilbert D, Sundby B, Gobeil C, Mucci A, Tremblay GH (2005) A seventy-two-year record of diminishing deep-water oxygen in the St. Lawrence estuary: the northwest Atlantic connection. Limnol Oceanogr 50(5):1654-1666

Gilliam FS (2006) Response of the herbaceous layer of forest ecosystems to excess nitrogen deposition. J Ecol 94(6): $1176-1191$

Gough L, Osenberg CW, Gross KL, Collins SL (2000) Fertilization effects on species density and primary productivity in herbaceous plant communities. Oikos 89:428-439

Greaver TL, Liu L, Bobbink R (2011) Chapter 17: Wetlands. In: Pardo LH, Robin-Abbott MJ, Driscoll CT (eds) Assessment of $\mathrm{N}$ deposition effects and empirical critical loads of $\mathrm{N}$ for ecoregions of the US. General Technical Report NRS-80. US Department of Agriculture, Forest Service, Northern Research Station, Newton Square, PA, p 291

Guisan A, Thuiller W (2005) Predicting species distribution: offering more than simple habitat models. Ecol Lett 8(9): 993-1009

H. John Heinz III Center for Science Economics and the Environment (2008) The state of the nation's ecosystems: measuring the lands, waters, and living resources of the United States. Island Press, Washington, DC

Haddad NM, Haarstad J, Tilman D (2000) The effects of longterm nitrogen loading on grassland insect communities. Oecologia 124(1):73-84

Haidinger TL, Keeley JE (1993) Role of high fire frequency in destruction of mixed chaparral. Madrono 40:141-147
Halman JM, Schaberg PG, Hawley GJ, Hansen CF (2011) Potential role of soil calcium in recovery of paper birch following ice storm injury in Vermont, USA. For Ecol Manage 261:1539-1545

Hartley AE, Neill C, Melillo JM, Crabtree R, Bowles FP (1999) Plant performance and soil nitrogen mineralization in response to simulated climate change in subarctic dwarf shrub heath. Oikos 86:331-343

Hartman MD, Baron JS, Ojima DS (2007) Application of a coupled ecosystem-chemical equilibrium model, DayCentChem, to stream and soil chemistry in a Rocky Mountain watershed. Ecol Model 200(3-4):493-510

Hautier Y, Niklaus PA, Hector A (2009) Competition for light causes plant biodiversity loss after eutrophication. Science 324(5927):636-638

Hector A, Bagchi R (2007) Biodiversity and ecosystem multifunctionality. Nature 448(7150):188-196

Hector A, Hautier Y, Saner P, Wacker L, Bagchi R, Joshi J, Scherer-Lorenzen M, Spehn EM, Bazeley-White E, Weilenmann M, Caldeira MC, Dimitrakopoulos PG, Finn JA, Huss-Danell K, Jumpponen A, Mulder CPH, Palmborg C, Pereira JS, Siamantziouras ASD, Terry AC, Troumbis AY, Schmid B, Loreau M (2010) General stabilizing effects of plant diversity on grassland productivity through population asynchrony and overyielding. Ecology 91(8): 2213-2220

HilleRisLambers J, Harpole WS, Schnitzer S, Tilman D, Reich PB (2009) $\mathrm{CO}(2)$, nitrogen, and diversity differentially affect seed production of prairie plants. Ecology 90(7): $1810-1820$

Hobbie SE (1996) Temperature and plant species control over litter decomposition in Alaskan tundra. Ecol Monogr 66(4): 503-522

Hobbs WO, Telford RJ, Birks HJB, Saros JE, Hazewinkel RRO, Perren BB, Saulnier-Talbot E, Wolfe AP (2010) Quantifying recent ecological changes in remote lakes of North America and Greenland using sediment diatom assemblages. PLoS One 5(3)

Hooper DU, Johnson L (1999) Nitrogen limitation in dryland ecosystems: responses to geographical and temporal variation in precipitation. Biogeochemistry 46(1-3):247-293

Howarth RW (1998) An assessment of human influences on fluxes of nitrogen from the terrestrial landscape to the estuaries and continental shelves of the North Atlantic Ocean. Nutr Cycl Agroecosyst 52(2-3):213-223

Howarth RW, Swaney DP, Butler TJ, Marino R (2000) Climatic control on eutrophication of the Hudson River estuary. Ecosystems 3(2):210-215

Howarth R, Chan F, Conley DJ, Garnier J, Doney SC, Marino R, Billen G (2011) Coupled biogeochemical cycles: eutrophication and hypoxia in temperate estuaries and coastal marine ecosystems. Front Ecol Environ 9(1):18-26

Hu S, Chapin FS, Firestone MK, Field CB, Chiariello NR (2001) Nitrogen limitation of microbial decomposition in a grassland under elevated CO2. Nature 409:188-191

Hubbell SP (2001) The unified neutral theory of biodiversity and biogeography. Princeton University Press, Princeton

Hurd TM, Brach AR, Raynal DJ (1998) Response of understory vegetation of Adirondack forests to nitrogen additions. Can J For Res 28:799-807 
Hurtt GC, Pacala SW (1995) The consequences of recruitment limitation-reconciling chance, history and competitive differences between plants. J Theor Biol 176(1):1-12

Huxman TE, Hamerlynck EP, Smith SD (1999) Reproductive allocation and seed production in Bromus madritensis ssp. rubens at elevated atmospheric $\mathrm{CO}(2)$. Funct Ecol 13(6): 769-777

Inouye RS (2006) Effects of shrub removal and nitrogen addition on soil moisture in sagebrush steppe. J Arid Environ 65:604-618

Inouye DW (2008) Effects of climate change on phenology, frost damage, and floral abundance of montane wildflowers. Ecology 89(2):353-362

IPCC (2007) The Physical Science Basis Contribution of Working Group I to the Fourth Assessment Report of the Intergovernmental Panel on Climate Change. Climate Change. Cambridge University Press, Cambridge

Jablonski LM, Wang XZ, Curtis PS (2002) Plant reproduction under elevated $\mathrm{CO}_{2}$ conditions: a meta-analysis of reports on 79 crop and wild species. New Phytol 156(1):9-26

Jeffries M (2006) Invertebrate communities and turnover in wetland ponds affected by drought. Freshw Biol 32: 603-612

Johnson NC, Rowland DL, Corkidi L, Egerton-Warburton LM, Allen EB (2003) Nitrogen enrichment alters mycorrhizal allocation at five mesic to semiarid grasslands. Ecology 84(7):1895-1908

Jordan TE, Whigham DF, Hofmockel KH, Pittek MA (2003) Nutrient and sediment removal by a restored wetland receiving agricultural runoff. J Environ Qual 32(4): 1534-1547

Karl TR, J. M, Peterson T, Hassol SJ (2009) Global climate change impacts in the United States. Cambridge University Press., Cambridge. http://www.globalchange.gov/publications/ reports/scientific-assessments/us-impacts/full-report/globalclimate-change

Keenan T, Serra JM, Lloret F, Ninyerola M, Sabate S (2011) Predicting the future of forests in the Mediterranean under climate change, with niche- and process-based models: CO(2) matters! Glob Change Biol 17(1):565-579

Keller JK, White JR, Bridgham SD, Pastor J (2004) Climate change effects on carbon and nitrogen mineralization in peatlands through changes in soil quality. Glob Change Biol 10(7):1053-1064

Kelly RP, Foley MM, Fisher WS, Feely RA, Halpern BS, Waldbusser GG, Caldwell MR (2011) Mitigating local causes of ocean acidification with existing laws. Science 332(6033): 1036-1037

Kleijn D, Rundlof M, Scheper J, Smith HG, Tscharntke T (2011) Does conservation on farmland contribute to halting the biodiversity decline? Trends Ecol Evol 26(9):474-481

Knapp AK, Smith MD (2001) Variation among biomes in temporal dynamics of aboveground primary production. Science 291:481-484

Knapp AK, Hamerlynck EP, Owensby CE (1993) Photosynthetic and water relations responses to elevated $\mathrm{CO}_{2}$ in the C4 grass Andropogon gerardii. Int J Plant Sci 154:459-466

Knapp AK, Hamerlynck EP, Ham JM, Owensby CE (1996) Responses in stomatal conductance to elevated $\mathrm{CO}_{2}$ in 12 grassland species that differ in growth form. Vegetatio $125: 31-41$
Knapp AK, Briggs JM, Hartnett DC, Collins SL (1998) Grassland dynamics: long-term ecological research in tallgrass prairie. Oxford University Press, New York

Korner C (2004) Mountain biodiversity, its causes and function. AMBIO 13:11-17

Langley JA, Megonigal JP (2010) Ecosystem response to elevated $\mathrm{CO}(2)$ levels limited by nitrogen-induced plant species shift. Nature 466(7302):96-99

Latimer JS, Rego SA (2010) Empirical relationship between eelgrass extent and predicted watershed-derived nitrogen loading for shallow New England estuaries. Estuaries Coasts 90:231-240

Lauenroth WK, Dodd JL, Simms PL (1978) The effects of water- and nitrogen-induced stresses on plant community structure in a semiarid grassland. Oecologia 36:211-222

Leach MK, Givnish TJ (1996) Ecological determinants of species loss in remnant prairies. Science 273:1555-1558

LeBauer DS, Treseder KK (2008) Nitrogen limitation of net primary productivity in terrestrial ecosystems is globally distributed. Ecology 89(2):371-379

Lilleskov EA, Wargo PM, Vogt KA, Vogt DJ (2008) Mycorrhizal fungal community relationship to root nitrogen concentration over a regional atmospheric nitrogen deposition gradient in the northeastern US. Can J For Res 38:1260-1266

Liu LL, Greaver TL (2009) A review of nitrogen enrichment effects on three biogenic GHGs: the $\mathrm{CO}(2)$ sink may be largely offset by stimulated $\mathrm{N}(2) \mathrm{O}$ and $\mathrm{CH}(4)$ emission. Ecol Lett 12(10):1103-1117

Loreau M, Mouquet N, Gonzalez A (2003) Biodiversity as spatial insurance in heterogeneous landscapes. Proc Natl Acad Sci USA 100(22):12765-12770

Luo Y, Su B, Currie WS, Dukes JS, Finzi AC, Hartwig U, Hungate B, McMurtrie RE, Oren R, Parton WJ, Pataki DE, Shaw MR, Zak DR, Field CB (2004) Progressive nitrogen limitation of ecosystem responses to rising atmospheric carbon dioxide. Bioscience 54(8):731-739

Maskell LC, Smart SM, Bullock JM, Thompson K, Stevens CJ (2010) Nitrogen deposition causes widespread loss of species richness in British habitats. Glob Change Biol 16(2):671-679

Mattson WJ (1980) Herbivory in relation to plant nitrogencontent. Annu Rev Ecol Syst 11:119-161

McKee JK, Sciulli PW, Fooce CD, Waite TA (2004) Forecasting global biodiversity threats associated with human population growth. Biol Conserv 115(1):161-164

McKinney ML, Lockwood JL (1999) Biotic homogenization: a few winners replacing many losers in the next mass extinction. Trends Ecol Evol 14(11):450-453

McNulty SG, Boggs JL (2010) A conceptual framework: redefining forest soil's critical acid loads under a changing climate. Environ Pollut 158(6):2053-2058

Mendelssohn IA (1979) The influence of nitrogen level, form, and application method on the growth response of Spartina alterniflora in North Carolina. Estuaries 2:106-118

Millennium Ecosystem Assessment (2005) Ecosystems and human well-being: biodiversity synthesis. World Resources Institute, Washington, DC

Mitton JB, Ferrenberg SM (2012) Mountain pine beetle develops an unprecedented summer generation in response to climate warming. Am Nat 179:E164-E171 
Morris JT (1991) Effects of nitrogen loading on wetland ecosystems with particular reference to atmospheric deposition. Annu Rev Ecol Syst 22:257-279

Najjar RG, Pyke CR, Adams MB, Breitburg D, Hershner C, Kemp M, Howarth R, Mulholland MR, Paolisso M, Secor D, Sellner K, Wardrop D, Wood R (2010) Potential climate-change impacts on the Chesapeake Bay. Estuar Coast Shelf Sci 86:1-20

National Climate Assessment (NCA) (2009) Global climate change impacts in the United States. Cambridge University Press, Cambridge

National Research Council (2000) Clean coastal waters: understanding and reducing the effects of nutrient pollution. National Research Council. National Academy Press, Washington, DC

Nordin A, Strengbom J, Witzell J, Näsholm T, Ericson L (2005) Nitrogen deposition and the biodiversity of boreal forests: implications for the nitrogen critical load. AMBIO 34: 20-24

Nowinski NS, Trumbore SE, Schuur EAG, Mack MC, Shaver GR (2008) Nutrient addition prompts rapid destabilization of organic matter in an arctic tundra ecosystem. Ecosystems 11:16-25

Noy-Meir I (1973) Desert ecosystems: environments and producers. Annu Rev Ecol Syst 4:25-51

Olff H, Ritchie ME (1998) Effects of herbivores on grassland plant diversity. Trends Ecol Evol 13(7):261-265

Paerl HW (2006) Assessing and managing nutrient-enhanced eutrophication in estuarine and coastal waters: interactive effects of human and climatic perturbations. Ecol Eng 26(1): 40-54

Paerl HW, Scott JT (2010) Throwing fuel on the fire: synergistic effects of excessive nitrogen inputs and global warming on harmful algal blooms. Environ Sci Technol 44(20):77567758

Pardo LH, Fenn M, Goodale CL, Geiser LH, Driscoll CT, Allen E, Baron J, Bobbink R, Bowman WD, Clark C, Emmett B, Gilliam FS, Greaver T, Hall SJ, Lilleskov EA, Liu L, Lynch J, Nadelhoffer K, Perakis S, Robin-Abbott MJ, Stoddard J, Weathers K, Dennis RL (2011a) Effects of nitrogen deposition and empirical nitrogen critical loads for ecoregions of the United States. Ecol Appl 21: 3049-3082

Pardo LH, Fenn ME, Goodale CL, Geiser LH, Driscoll CT, Allen EB, Baron JS, Bobbink R, Bowman WD, Clark CM, Emmett B, Gilliam FS, Greaver TL, Hall SJ, Lilleskov EA, Liu L, Lynch JA, Nadelhoffer KJ, Perakis SS, RobinAbbott MJ, Stoddard JL, Weathers KC, Dennis RL (2011b) Effects of nitrogen deposition and empirical nitrogen critical loads for ecoregions of the United States. Ecol Appl 21(8):3049-3082

Parmesan C (2006) Ecological and evolutionary responses to recent climate change. Annu Rev Ecol Evol Syst 37: 637-669

Peel JL, Haeuber R, Garcia V, Russell AG, Neas L. Impact of nitrogen and climate change interactions on ambient air pollution and human health. Biogeochemistry. doi:10.1007/ s10533-012-9782-4

Pereira HM, Leadley PW, Proenca V, Alkemade R, Scharlemann JPW, Fernandez-Manjarres JF, Araujo MB, Balvanera P, Biggs R, Cheung WWL, Chini L, Cooper HD,
Gilman EL, Guenette S, Hurtt GC, Huntington HP, Mace GM, Oberdorff T, Revenga C, Rodrigues P, Scholes RJ, Sumaila UR, Walpole M (2010) Scenarios for global biodiversity in the 21st century. Science 330(6010): 1496-1501

Pimm SL, Russell GJ, Gittleman JL, Brooks TM (1995) The future of biodiversity. Science 269(5222):347-350

Raffa KF, Aukema BH, Bentz BJ, Carroll AL, Hicke JA, Turner MG, Romme WH (2008) Cross-scale drivers of natural disturbances prone to anthropogenic amplification: the dynamics of bark beetle eruptions. Bioscience 58(6):501-517

Rahel FJ, Olden JD (2008) Assessing the effects of climate change on aquatic invasive species. Conserv Biol 22(3): 521-533

Rao LE, Allen EB (2010) Combined effects of precipitation and nitrogen deposition on native and invasive winter annual production in California deserts. Oecologia 162(4):1035-1046

Rao LE, Allen EB, Meixner T (2010) Risk-based determination of critical nitrogen deposition loads for fire spread in southern California deserts. Ecol Appl 20:1320-1335

Reich PB (2009) Elevated CO(2) reduces losses of plant diversity caused by nitrogen deposition. Science 326(5958): 1399-1402

Reich PB, Hungate BA, Luo YQ (2006) Carbon-nitrogen interactions in terrestrial ecosystems in response to rising atmospheric carbon dioxide. Annu Rev Ecol Evol Syst 37:611-636

Ricklefs RE (1987) Community diversity: relative roles of local and regional processes. Science 235:167-171

Ricklefs RE (2004) A comprehensive framework for global patterns in biodiversity. Ecol Lett 7:1-15

Rockström J, Steffen W, Noone K, Persson A, Chapin F, Lambin EF, Lenton TM, Scheffer M, Folke C, Schellnhuber HJ, Nykvist B, de Wit CA, Hughes T, van der Leeuw S, Rodhe H, Sörlin S, Snyder PK, Costanza R, Svedin U, Falkenmark M, Karlberg L, Corell R, Fabry VJ, Hansen J, Walker B, Liverman D, Richardson K, Crutzen P, Foley JA (2009) A safe operating space for humanity. Nature 461: $472-475$

Rosenzweig ML (1995) Species diversity in space and time. Cambridge University Press, New York

Rosenzweig ML, Abramsky Z (1993) How are diversity and productivity related? In: Ricklefs RE, Schluter D (eds) Species diversity in ecological communities. University of Chicago Press, Chicago, pp 52-65

Rowe EC, Moldan F, Emmett BA, Evans CD, Hellsten S (2005) Model chains for assessing the impacts of nitrogen on soils, waters and biodiversity: a review. NERC/Centre for Ecology \& Hydrology (CEH Project Number: C02887)

Roy HE, Hails RS, Hesketh H, Roy DB, Pell JK (2009) Beyond biological control: non-pest insects and their pathogens in a changing world. Insect Conserv Divers 2(2):65-72

Sabo JL, Finlay JC, Kennedy T, Post DM (2010) The role of discharge variation in scaling of drainage area and food chain length in rivers. Science 330(6006):965-967

Sala OE, Chapin FS, Armesto JJ, Berlow E, Bloomfield J, Dirzo R, Huber-Sanwald E, Huenneke LF, Jackson RB, Kinzig A, Leemans R, Lodge DM, Mooney HA, Oesterheld M, Poff NL, Sykes MT, Walker BH, Walker M, Wall DH (2000) Biodiversity - global biodiversity scenarios for the year 2100. Science 287(5459):1770-1774 
Samson F, Knopf F (1994) Prairie conservation in North America. Bioscience 44:418-421

Saros JE, Rose KC, Clow DW, Stephens VC, Nurse AB, Arnett HA, Stone JR, Williamson CE, Wolfe AP (2010) Melting Alpine Glaciers Enrich High-Elevation Lakes with Reactive Nitrogen. Environ Sci Technol 44(13):4891-4896

Scavia D, Field J, Boesch D, Buddemeier R, Burkett V, Cayan D, Fogarty M, Harwell M, Howarth R, Mason C, Reed D, Royer T, Sallenger A, Titus J (2002) Climate change impacts on US coastal and marine ecosystems. Estuaries Coasts 25(2):149-164

Schaberg PG, DeHayes DH, Hawley GJ, Murakami PF, Strimbeck GR, McNulty SG (2002) Effects of chronic N fertilization on foliar membranes, cold tolerance, and carbon storage in montane red spruce. Can J For Res 32(8): 1351-1359

Scherber C, Eisenhauer N, Weisser WW, Schmid B, Voigt W, Fischer M, Schulze ED, Roscher C, Weigelt A, Allan E, Bessler H, Bonkowski M, Buchmann N, Buscot F, Clement LW, Ebeling A, Engels C, Halle S, Kertscher I, Klein AM, Koller R, Konig S, Kowalski E, Kummer V, Kuu A, Lange M, Lauterbach D, Middelhoff C, Migunova VD, Milcu A, Muller R, Partsch S, Petermann JS, Renker C, Rottstock T, Sabais A, Scheu S, Schumacher J, Temperton VM, Tscharntke T (2010) Bottom-up effects of plant diversity on multitrophic interactions in a biodiversity experiment. Nature 468(7323):553-556

Secretariat of the Convention on Biological Diversity (2003) Handbook of the convention on biological diversity. Earthscan, London

Secretariat of the Convention on Biological Diversity (2006a) Global biodiversity outlook 2. SCBD, Montreal

Secretariat of the Convention on Biological Diversity (2006b) Global biodiversity outlook 3. SCBD, Montreal

Shaver GR, Johnson LC, Cades DH, Murray G, Laundre JA, Rastetter EB, Nadelhoffer KJ, Giblin AE (1998) Biomass and $\mathrm{CO}_{2}$ flux in wet sedge tundras: responses to nutrients, temperature, and light. Ecol Monogr 68:75-97

Shaver GR, Bret-Harte SM, Jones MH, Johnstone J, Gough L, Laundre J, Chapin FS (2001) Species composition interacts with fertilizer to control long-term change in tundra productivity. Ecology 82(11):3163-3181

Shaw MR, Zavaleta ES, Chiariello NR, Cleland EE, Mooney HA, Field CB (2002) Grassland responses to global environmental changes suppressed by elevated $\mathrm{CO}_{2}$. Science 298(5600):1987-1990

Sheppard LJ, Pfanz H (2001) Impacts of air pollutants on cold hardiness. In: Bigras FJ, Colombo SJ (eds) Conifer cold hardiness. Kluwer, Dordrecht, pp 335-366

Sinervo B, Mendez-de-la-Cruz F, Miles DB, Heulin B, Bastiaans E, Cruz MVS, Lara-Resendiz R, Martinez-Mendez N, Calderon-Espinosa ML, Meza-Lazaro RN, Gadsden H, Avila LJ, Morando M, De la Riva IJ, Sepulveda PV, Rocha CFD, Ibarguengoytia N, Puntriano CA, Massot M, Lepetz V, Oksanen TA, Chapple DG, Bauer AM, Branch WR, Clobert J, Sites JW (2010) Erosion of lizard diversity by climate change and altered thermal niches. Science 328 (5980):894-899
Stevens CJ, Dise NB, Mountford JO, Gowing DJ (2004) Impact of nitrogen deposition on the species richness of grasslands. Science 303(5665):1876-1879

Stevens CJ, Dupre C, Dorland E, Gaudnik C, Gowing DJG, Bleeker A, Diekmann M, Alard D, Bobbink R, Fowler D, Corcket E, Mountford JO, Vandvik V, Aarrestad PA, Muller S, Dise NB (2010) Nitrogen deposition threatens species richness of grasslands across Europe. Environ Pollut 158(9):2940-2945

Sturm M, Racine C, Tape K (2001) Climate change-increasing shrub abundance in the Arctic. Nature 411(6837): $546-547$

Sturm M, Schimel J, Michaelson G, Welker JM, Oberbauer SF, Liston GE, Fahnestock J, Romanovsky VE (2005) Winter biological processes could help convert arctic tundra to shrubland. Bioscience 55(1):17-26

Sverdrup H, Belyazid S, Nihlgård B, Ericson L (2007) Modelling change in ground vegetation response to acid and nitrogen pollution, climate change and forest management at in Sweden 1500-2100 a.d. Water Air Soil Pollut Focus 7(1):163-179

Sverdrup H, McDonnell TC, Sullivan TJ, Nihlgard B, Belyazid S, Rihm B, Porter E, Bowman WD, Geiser L (2012) Testing the feasibility of using the ForSAFE-VEG model to map the critical load of nitrogen to protect plant biodiversity in the rocky mountains region, USA. Water Air Soil Pollut 223:371-387

Sylvan JB, Dortch Q, Nelson DM, Brown AFM, Morrison W, Ammerman JW (2006) Phosphorus limits phytoplankton growth on the Louisiana shelf during the period of hypoxia formation. Environ Sci Technol 40(24):7548-7553

Thomas RQ, Canham CD, Weathers KC, Goodale CL (2010) Increased tree carbon storage in response to nitrogen deposition in the US. Nat Geosci 3:13-17

Thompson K, Bakker JP, Bekker RM, Hodgson JG (1998) Ecological correlates of seed persistence in soil in the north-west European flora. J Ecol 86(1):163-169

Throop HL, Lerdau MT (2004) Effects of nitrogen deposition on insect herbivory: implications for community and ecosystem processes. Ecosystems 7(2):109-133

Thurig B, Korner C, Stocklin J (2003) Seed production and seed quality in a calcareous grassland in elevated $\mathrm{CO}_{2}$. Glob Change Biol 9(6):873-884

Tilman D (1993) Species richness of experimental productivity gradients: how important is colonization limitation. Ecology 74:2179-2191

Tilman D, Haddi A (1992) Drought and biodiversity in grasslands. Oecologia 89(2):257-264

Tilman D, Lehman CL, Bristow CE (1998) Diversity-stability relationships: statistical inevitability or ecological consequence? Am Nat 151(3):277-282

Tyler AC, Lambrinos JG, Grosholz ED (2007) Nitrogen inputs promote the spread of an invasive marsh grass. Ecol Appl 17:1886-1898

UBA (UmweltBundesAmt) (2004) Manual on methodologies and criteria for mapping critical levels/loads and geographical areas where they are exceeded. Federal Environmental Agency (UmweltBundesAmt), Berlin, 
Germany. http://www.rivm.nl/en/themasites/icpmm/manualand-downloads/manual-english/index.html

USDA-NRCS (US Department of Agriculture Natural Resources Conservation Service) (2009) The PLANTS database. National Plant Data Center, Baton Rouge, Louisiana, USA. http://plants.usda.govi

US-EPA (US Environmental Protection Agency) (2011) Reactive nitrogen in the United States: an analysis of inputs, flows, consequences, and management options a report of the EPA Science Advisory Board, EPA-SAB-11-013, Washington, DC

US-Fish and Wildlife Service (2011) Species Report. http:// ecos.fws.gov/tess_public/pub/Boxscore.do

Van Oorschot M, Ros J, Notenboom J (2010) Evaluation of the indirect effects of biofuel production on biodiversity: assessment across spatial and temporal scales. Netherlands Environmental Assessment Agency (PBL), Bilthoven

Van Wijk MT, Clemmensen KE, Shaver GR, Williams M, Callaghan TV, Chapin FS, Cornelissen JHC, Gough L, Hobbie SE, Jonasson S, Lee JA, Michelsen A, Press MC, Richardson SJ, Rueth H (2004) Long-term ecosystem level experiments at Toolik Lake, Alaska, and at Abisko, Northern Sweden: generalizations and differences in ecosystem and plant type responses to global change. Glob Change Biol 10(1):105-123

Vitousek PM, Howarth RW (1991) Nitrogen limitation on land and in the sea: how can it occur? Biogeochemistry 13: $87-115$

Vitousek PM, Aber JD, Howarth RW, Likens GE, Matson PA, Schindler DW, Schlesinger WH, Tilman DG (1997) Human alteration of the global nitrogen cycle: sources and consequences. Ecol Appl 7(3):737-750

Waide RB, Willig MR, Steiner CF, Mittelbach G, Gough L, Dodson SI, Juday GP, Parmenter R (1999) The relationship between productivity and species richness. Annu Rev Ecol Syst 30:257-300

Weathers KC, Lynch JA (2011) Chapter 3: deposition. In: Pardo LH, Robin-Abbott MJ \& Driscoll CT (eds) Assessment of nitrogen deposition effects and empirical critical loads of nitrogen for ecoregions of the United States, General Technical Report NRS-80. Department of Agriculture, Forest Service, Northern Research Station, Newtown Square, PA, p 291

Weathers KC, Simkin SM, Lovett GM, Lindberg SE (2006) Empirical modeling of atmospheric deposition in mountainous landscapes. Ecol Appl 16(4):1590-1607

Wedin DA, Tilman D (1996) Influence of nitrogen loading and species composition on the carbon balance of grasslands. Science 274:1720-1723

Weedon TJ, Kowalchuk A, Aerts R, van Hal J, van Logtestijn R, Taş N, Röling FM, van Bodegom M (2012) Summer warming accelerates sub-arctic peatland nitrogen cycling without changing enzyme pools or microbial community structure. Glob Change Biol 18(1):138-150
Wigand C, McKinney RA, Charpentier MA, Chintala MM, Thursby GB (2003) Relationships of nitrogen loadings, residential development, and physical characteristics with plant structure in New England salt marshes. Estuaries 26:1494-1504

Wigand C, Brennan P, Stolt M, Holt M, Ryba S (2009) Soil respiration rates in coastal marshes subject to increasing watershed nitrogen loads in southern New England, USA. Wetlands 29(3):952-963

Wolfe AP, Baron JS, Cornett RJ (2001) Anthropogenic nitrogen deposition induces rapid ecological changes in alpine lakes of the Colorado Front Range (USA). J Paleolimnol 25:1-7

Wood YA, Meixner T, Shouse PJ, Allen EB (2006) Altered ecohydrologic response drives native shrub loss under conditions of elevated nitrogen deposition. J Environ Qual 35(1):76-92

Wu W, Driscoll CT (2010) Impact of climate change on threedimensional dynamic critical load functions. Environ Sci Technol 44(2):720-726

Yachi S, Loreau M (1999) Biodiversity and ecosystem productivity in a fluctuating environment: the insurance hypothesis. Proc Natl Acad Sci USA 96(4):1463-1468

Yang HJ, Li Y, Wu MY, Zhang Z, Li LH, Wan SQ (2011a) Plant community responses to nitrogen addition and increased precipitation: the importance of water availability and species traits. Glob Change Biol 17(9):2936-2944

Yang HJ, Wu MY, Liu WX, Zhang Z, Zhang NL, Wan SQ (2011b) Community structure and composition in response to climate change in a temperate steppe. Glob Change Biol 17(1):452-465

Zavaleta ES, Shaw MR, Chiariello NR, Mooney HA, Field CB (2003a) Additive effects of simulated climate changes, elevated $\mathrm{CO}_{2}$, and nitrogen deposition on grassland diversity. Proc Natl Acad Sci 100(13):7650-7654

Zavaleta ES, Shaw MR, Chiariello NR, Thomas BD, Cleland EE, Field CB, Mooney HA (2003b) Grassland responses to three years of elevated temperature, $\mathrm{CO}(2)$, precipitation, and $\mathrm{N}$ deposition. Ecol Monogr 73(4):585-604

Zavaleta ES, Thomas BD, Chiariello NR, Asner GP, Shaw MR, Field CB (2003c) Plants reverse warming effect on ecosystem water balance. Proc Natl Acad Sci USA 100(17): 9892-9893

Zavaleta ES, Pasari JR, Hulvey KB, Tilman GD (2010) Sustaining multiple ecosystem functions in grassland communities requires higher biodiversity. Proc Natl Acad Sci USA 107(4):1443-1446

Zedler J, Shabman L, Alvarez V, Evans RO, Gardner RC, Gibbons JW, Gilliam JW, Johnston CA, Mitsch WJ, Prestegaard K, Redmond AM, Simenstad C, Turner RE (2001) Compensating for wetland loss under the Clean Water Act. National Academy Press, Washington, DC

Zobel M (1997) The relative role of species pools in determining plant species richness. An alternative explanation of species coexistence? Trends Ecol Evol 12(7):266-269 